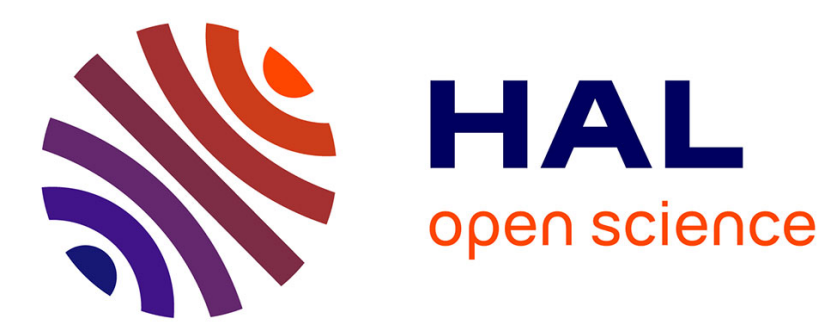

\title{
The Quest for Pro-poor and Inclusive Growth: The Role of Governance
}

Djeneba Doumbia

\section{To cite this version:}

Djeneba Doumbia. The Quest for Pro-poor and Inclusive Growth: The Role of Governance. 2018. halshs-01945812

\section{HAL Id: halshs-01945812 \\ https://shs.hal.science/halshs-01945812}

Preprint submitted on 5 Dec 2018

HAL is a multi-disciplinary open access archive for the deposit and dissemination of scientific research documents, whether they are published or not. The documents may come from teaching and research institutions in France or abroad, or from public or private research centers.
L'archive ouverte pluridisciplinaire HAL, est destinée au dépôt et à la diffusion de documents scientifiques de niveau recherche, publiés ou non, émanant des établissements d'enseignement et de recherche français ou étrangers, des laboratoires publics ou privés. 


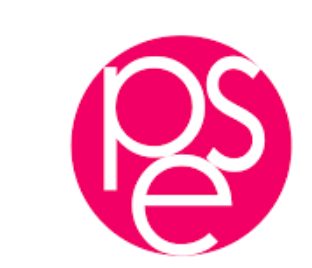

PARISSCHOOL OFECONOMICS
ECOLED'ECONOMIEDE PARIS

WORKING PAPER N ${ }^{\circ} 2018-50$

The Quest for Pro-poor and Inclusive Growth: The Role of Governance

\author{
Djeneba Doumbia
}

JEL Codes: C23, G28, 011, 057

Keywords: Pro-poor growth, Inclusive growth, Governance, PSTR
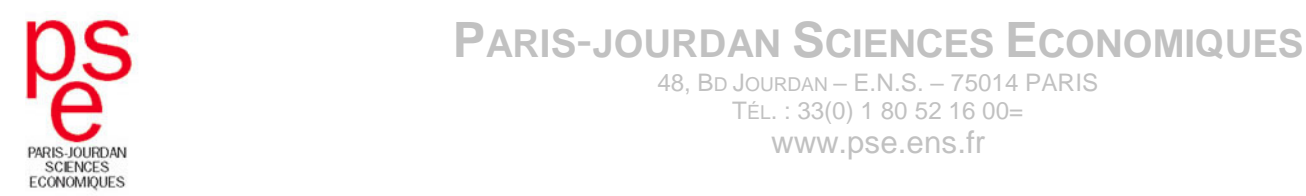


\title{
The Quest for Pro-poor and Inclusive Growth: The Role of Governance ${ }^{1}$
}

\author{
Djeneba Doumbia \\ Paris School of Economics \\ University Paris I Pantheon-Sorbonne \\ World Bank
}

\begin{abstract}
This paper analyses the role of good governance in fostering pro-poor and inclusive growth. Using a sample of 112 countries over 1975-2012, it shows that growth is generally pro-poor. However, growth has not been inclusive, as illustrated by a decline in the bottom 20 percent of the income distribution. While all features of good governance support income growth and reduce poverty, only government effectiveness and the rule of law are found to enhance inclusive growth. The investigation of the determinants of pro-poor and inclusive growth highlights that education, infrastructure improvement, and financial development are the key factors in poverty reduction and inclusive growth. Relying on the panel smooth transition regression (PSTR) model following Gonzalez, Tersvirta and Dijk (2005), the paper identifies a nonlinear relationship between governance and pro-poor growth, while the impact of governance on inclusive growth appears to be linear.
\end{abstract}

Keywords: Pro-poor growth, Inclusive growth, Governance, PSTR

JEL Classification: C23, G28, O11, O57

\footnotetext{
${ }^{1}$ The author is grateful to Jean-Bernard Chatelain, Jean-Louis Combes, Philippe de Vreyer, Ivailo Izvorski, Tidiane Kinda, Aart Kraay, participants to the African Development Bank and UNDP 2015 Annual Economic Conference and to the two anonymous referees whose comments led to substantial improvements in the paper. I am also thankful to David Dollar, Aart Kraay and Tatjana Kleineberg for making their data on the income of the poor available.

The findings, interpretations, and conclusions expressed in this paper are entirely those of the author and should not be attributed in any manner to the World Bank.
} 


\section{Introduction}

Poverty remains widespread, particularly in developing countries, notwithstanding recent progress. While the aggregate worldwide poverty rate was reduced by about half between 1990 and 2010, mainly thanks to robust growth, the World Bank estimates that more than 1.2 billion people were living on less than $\$ 1.25$ a day in 2010. To contrast the encouraging dynamic in poverty reduction, income inequality has risen across the world over the last two decades. How do these two divergent dynamics impact the income opportunities of the less fortunate, namely, the poorest 20 percent of the population? This is an important policy question that has led to the development of new concepts on pro-poor growth and an increased focus on income distribution with new studies on inclusive growth.

Numerous empirical and statistical studies have identified economic growth as one of the main factors affecting poverty reduction (Dollar and Kraay 2002; Dollar, Kleineberg and Kraay 2016). Moreover, there is a growing understanding that economic, political, legal and social institutions are critical for economic prosperity. Since the 1990s, the concept of good governance has become central in the discussion and design of development policies. Because both governance and pro-poor growth are important in the development policy agenda, the question arises whether and how they are related to each other.

This paper provides a cross-country analysis investigating the role of economic growth in poverty reduction and adds two main contributions to the existing literature. First, it contributes to the recent and growing literature on inclusive growth by assessing the extent to which growth has been pro-poor and inclusive. It also investigates the main structural factors that impact inclusive growth, with particular focus on an important channel that has received little attention so far: the quality of governance. Second, concentrating on governance, the paper investigates the potential nonlinearities in the impact of growth on the poor depending on the quality of governance.

The analysis therefore sheds some light on the role of governance in making growth more pro-poor and inclusive. Following Ravallion and Chen (2003), it defines growth as pro-poor if it reduces poverty or increases the income of the poor. Meanwhile, inclusive growth refers to growth that is not associated with an increase in inequality (Rauniyar and Kanbur 2010).

The paper relies on panel fixed effect estimations and the generalized method of moments in system (SYS-GMM) following Arrellano and Bover (1995). This method attempts to address endogeneity issues related to potentially endogenous explanatory variables. A second empirical method used in the study is the panel smooth transition regression (PSTR), following Gonzalez, Tersvirta and Dijk (2005). The PSTR models a nonlinear relationship and captures the speed of transition from one regime to the other, while the transition between the two regimes assumed to be gradual. 
The main findings are that (i) in general growth is pro-poor: the income of the poorest 20 percent increases with per capita income growth; (ii) globally, growth has not been inclusive; (iii) all features of good governance, especially the control of corruption, are pro-poor, but only two features-government effectiveness and rule of law-promote inclusive growth; (iv) structural factors such as education spending, infrastructure improvement, and financial development are key factors for promoting both poverty reduction and inclusive growth; and (v) the impact of growth on the income of the poor is nonlinear and declines with the level of corruption, but the impact of growth on the income share of the bottom 20 percent is linear.

The rest of the paper is structured as follows. Section II briefly reviews the literature on propoor growth and income distribution as well as the relationship between governance and propoor growth. Section III explains the econometric methodology. Section IV describes the data, and sections V and VI present empirical results. Section VII provides concluding remarks.

\section{Literature review}

\section{Growth, poverty, and income distribution}

This section discusses the cross-country empirical literature analysing the relationship between growth, poverty and income distribution.

In his seminal paper, Kuznets (1955) found evidence of an inverted-U relationship between the level of development and income inequality. As economies develop, inequality increases initially because growth tends to benefit a small segment of the population. Over time, inequality declines subsequently as a larger part of the population finds employment in the high-income sector. However, existing empirical evidence of the Kuznets curve is at best mixed. Deininger and Squire (1998) find no evidence of an inverted-U relationship between per capita income and inequality. They show that high growth was associated with declining inequality as often as it was related to increasing inequality, or no changes at all. Ravallion and Chen (1997) highlight that changes in inequality and polarization were uncorrelated using household surveys in 67 developing and transnational economies over 1981-94. They show that income distribution improved as often as it worsened in growing economies, and negative growth was often more unfavourable to distribution than positive growth. Goudie and Ladd (1999) also find little evidence that growth systematically changes income distribution.

Empirical evidence on the reverse link - the impact of inequality on growth - is similarly mixed. For instance, Forbes (2000) shows that an increase in income inequality has a significant positive effect on economic growth in the short and medium term. Alesina and Rodrik (1994) illustrate, in a political economy context, that, if inequality is high, the poor have less voice and accountability. In such a context, the median voter will push for 
distortionary taxes, which will have discouraging effects on savings and hamper growth. Berg and Ostry (2011) find that lower income inequality is associated with sustained growth spells.

Few other studies have analysed the impact of inequality on poverty. Deininger and Squire (1998) examine how initial inequality and concomitant changes in inequality impact poverty. They find that the poorest 20 percent suffer the most from the growth-decreasing effects of inequality. Initial inequality also hurts the poor through credit rationing and powerlessness to invest. Ravallion (2001) also shows that the poor might gain more from redistribution, but suffer more than the rich from economic shrinkage.

\section{Governance and pro-poor growth}

A large number of studies have investigated the role of good governance in economic development and poverty reduction. Kaufmann and Aart (2002) identify a strong positive correlation between per capita income and the quality of governance across countries. The authors also highlight a strong positive causal effect running from better governance to higher per capita income. However, they find a weak, even negative causal effect running from per capita income to governance, not supporting a possible virtuous circle whereby higher income leads to improvement in governance.

Dollar and Kraay (2002) find that greater rule of law is associated with a larger share of the growth dividend accruing to the poorest 20 percent of the population. Kraay (2004) finds similar results. Resnick and Regina (2006) develop a conceptual framework specifying the relationship between different aspects of governance and pro-poor growth. Using this framework, they review a range of quantitative cross-country studies analysing pro-poor growth and including indicators of governance as independent variables. The review indicates that governance indicators, such as measures of political stability and rule of law, are associated with higher growth, but provides mixed results regarding poverty reduction. However, governance indicators related to transparency, such as measures of civil liberties and political freedom, tend to foster poverty reduction, but the evidence is rather mixed on the relationship between these variables and growth. Providing a different perspective, Lopez (2004) assesses whether policies that are pro-growth are also pro-poor. He finds that policies tend to be poverty reducing in the long run rather than the short run. He also argues that political economy constraints could prevent these policies from being sustained sufficiently to reduce poverty. Kraay (2004) finds that better rule of law and enhanced accountability are both positively correlated with higher growth. White and Anderson (2001) argue that civil liberties and political freedom are pro-poor and that political freedom has a much larger impact. 


\section{Econometric methodology}

This section describes the main empirical framework underlying the analysis. The analysis covers 112 developed and developing countries. ${ }^{2}$ Following various empirical studies on economic growth, the paper relies on 10 non-overlapping four-year periods to control for business cycle fluctuations during the sample period (1975-2012). ${ }^{3}$

The following equation forms the basis of the empirical strategy:

$\ln Y_{i t}=\beta \operatorname{lnGDPpc} c_{i t}+\gamma \operatorname{lnGINI_{it}}+\beta_{G o v} G_{o v}+\beta_{X} X_{i t}+\alpha_{i}+\mu_{t}+\varepsilon_{i t}$,

where $Y_{i t}$ is a vector of the three distinct dependent variables capturing poverty and inclusiveness for each country $i$ during period $t$ : (i) the income of the poorest 20 percent in the income distribution $\left(y p_{i t}\right)$; (ii) the poverty headcount ratio at $\$ 2$ a day in purchasing power parity (PPP) $\left(P_{i t}\right)$; and (iii) the income share of the poorest 20 percent $\left(Q_{i t}\right)$. $\operatorname{lnGDPp} c_{i t}$ is the logarithm of gross domestic product (GDP) per capita. Following Ravallion and Chen (1997), the paper also controls for the logarithm of the Gini index (lnGINI $I_{i t}$ ) to control for the potential impact of income distribution on poverty. ${ }^{4} G o v_{i t}$ denotes a set of the six governance indicators, plus the aggregated indicator of governance, which is obtained using principal component analysis. $X_{i t}$ represents the set of control variables. This set includes variables related to health, human capital, infrastructure, openness to trade, employment, and financial factors. These control variables reflect the state of the empirical literature on the determinants of economic growth and poverty reduction. Appendix table A2 summarizes the description and source of the variables, and table A3 presents statistical summaries of the main variables. Country-specific effects are indicated by $\alpha_{i} ; \mu_{t}$ is timespecific effects; and $\varepsilon_{i t}$ is the time-varying error term.

In addition to fixed effects estimations, the paper also relies on the generalized method of moments in system (SYS-GMM) to address potential endogeneity arising through reverse causality as well as allowing for a dynamic process, which may be more appropriate in analysing persistent phenomenon over time such as poverty and inclusiveness.

\footnotetext{
${ }^{2}$ Appendix table A1 presents the list of countries.

${ }^{3}$ The latter period is the mean of the two previous years. The results remain unchanged if the baseline results are reproduced without the two previous years. This approach has been used in the literature. For instance, Giuliano and Ruiz-Arranz (2009) split their sample period into six nonoverlapping five-year periods, except for the last period, which is the average of the three previous years.

${ }^{4}$ Growth in average income can shift the income distribution, while variations in inequality can also change the shape of income distribution. Both of these effects can impact the income of the poor and the poverty headcount ratios.
} 


\section{Data}

\section{Measuring Poverty and Inequality}

The paper uses two main datasets to capture poverty and inclusiveness. The income of the bottom 20 percent and the income share of the first quintile are from the Dollar-KleinebergKraay dataset. ${ }^{5}$ This dataset builds on a larger dataset of 963 country-year observations for which household surveys are available. It emerges from the fusion of the Luxembourg Income Study (LIS) database, covering mostly developed countries, and the World Bank's PovcalNet database, covering essentially developing countries. The LIS survey means are converted to constant 2005 U.S. dollars to be consistent with PovcalNet data. The DollarKleineberg-Kraay dataset covers 151 countries between 1967 and 2011.

The poverty headcount ratio at \$2 PPP a day is from the World Development Indicators (WDI) database. This measure is based on the percentage of the population living on less than $\$ 2$ a day at 2005 international U.S. dollar prices. In addition, the paper measures mean income - per capita income - as real per capita GDP at constant 2005 PPP international U.S. dollars. ${ }^{6}$ The logarithm of the Gini index is the measure of inequality used in this paper.

\section{Defining and measuring governance}

The concept of governance is widely discussed among scholars and policy makers. It means different things to different people. Consequently, there are varying definitions of governance. Theoretically, governance can be defined as the rule of the rulers, typically within a given set of rules. In the context of economic growth and poverty reduction, governance refers to essential parts of the wide-ranging cluster of institutions. The United Nations Development Program (UNDP 1997) defines governance as "the exercise of economic, political, and administrative authority to manage a country's affairs at all levels. It comprises mechanisms, processes, and institutions through which citizens and groups articulate their interests, exercise their legal rights, meet their obligations, and mediate their differences."

According to the World Bank (1992, 1), governance is "the process through which power is exercised in the management of a country's political, social, and economic institutions for development". Kaufmann, Kraay, and Zoido-Lobaton (1999) explain that the fundamental aspects of governance are graft, rule of law, and government effectiveness. Other dimensions are voice and accountability, political instability and violence, and regulatory burden. Within this notion of governance, the evident question is what is good governance? This paper associates the quality of governance with democracy and transparency, with the rule of law and good civil rights, and with efficient public services. Also, the quality of governance is

\footnotetext{
${ }^{5}$ See Dollar, D., Kleineberg T., and Kraay, A., 2016. "Growth Still Is Good for the Poor.” European Economic Review, Elsevier, vol. 81(C): 68-85.

${ }^{6}$ In the paper, per capita income and per capita GDP are equivalent.
} 
determined by the impact of this exercise of power on the quality of life enjoyed by the citizens.

To measure the concept of good governance, the paper uses the Worldwide Governance Indicators (WGI) database. The WGI database has been proposed by the World Bank to estimate good governance (Kaufmann, Kraay and Mastruzzi 2005). There exist three dimensions of governance: political, economic, and institutional. The six governance indicators can be classified into three groups of two indicators each. ${ }^{7}$ First, the political feature of governance should capture the process by which government is nominated, supervised, and replaced. The political feature encompasses two indicators: voice and accountability, along with political stability. The second dimension is economic governance, which includes government effectiveness and regulatory quality. The third dimension represents the institutional feature of governance. It involves indicators of the rule of law and the control of corruption.

\section{Main explanatory variables}

This subsection discusses the theoretical and expected impact of the main explanatory variables included in equation (1):

- Income per capita, measured by the logarithm of per capita GDP and the squared term to capture a potential Kuznets curve hypothesis. The Kuznets curve hypothesis predicts that inequality will increase with rising incomes in the initial stage of development and decrease at higher levels of development. Yet, the existing evidence for the Kuznets curve hypothesis is mixed (Barro 2008; Kanbur 2000; Woo et al. 2017).

- Human capital, captured by the ratio of the gross enrolment in secondary schooling. Studies find that improvements in human endowments through increases in education are strongly associated with poverty reduction and economic growth (Barro and Salai-Martin 2004 among others). Human capital can reduce poverty in three main ways (Berg 2008): (i) higher educational attainment leads to higher earnings; (ii) better quality and higher levels of education are associated with economic growth, which subsequently increases economic opportunities; (iii) higher levels of education are correlated with higher social benefits, improving the health care of the poor. In addition, in empirical studies, low educational attainment is often identified as a source of income inequality. Education expansion can help reduce income inequality (Corak 2013; De Gregorio and Lee 2002). However, the link between human capital accumulation and income inequality can be ambiguous (Knight and Sabot 1983).

\footnotetext{
${ }^{7}$ The point estimates range from -2.5 (weak governance) to 2.5 (strong governance).
} 
- Trade openness, measured by the sum of exports and imports in percent of GDP. The theoretical relationship between trade openness and poverty is ambiguous (Le Goff and Jan Singh 2014). This ambiguity is also present in the empirical literature. While some studies find that trade openness does not impact poverty (Beck, Demirgüç-Kunt, and Levine 2007; Kpodar and Singh 2011), others suggest a positive relationship between trade openness and poverty (Guillaumont-Jeanneney and Kpodar 2011; Singh and Huang 2011). In addition, Agénor (2004) finds an inverted U-shaped link between globalization and poverty. Globalization leads to decreases in poverty above a certain level of globalization. Regarding the relationship between trade openness and inequality, the literature has been inconclusive overall (Krugman 2008; Meschi and Vivarelli 2007) even though many studies show that trade openness is associated with lower income inequality (IMF 2007; Woo et al. 2017).

- Public spending, captured by public spending on education and health care in percent of GDP. The empirical literature suggests that higher spending on education and health care is associated with reduced income inequality and poverty.

- Basic needs, measured by the percentage of the population with access to improved sanitation. The poorest people tend to be the ones with no or limited access to basic services. Better access to improved sanitation is expected to reduce poverty.

- Inflation, measured by the change in the consumer price index. Inflation tends to worsen poverty (Agénor 1998; Powers 1995). It also tends to hurt the poor disproportionally and increase inequality (Albanesi 2007; Fischer and Modigliani 1978).

- Financial development and openness, captured by M2 and the Chinn Ito index of capital account openness. The relationship between financial sector development and economic growth has been well established in the empirical academic literature (King and Levine 1993; Levine 2005; Levine, Loayza, and Beck 2000). Finance can positively impact growth through capital accumulation and technological progress. Financial systems produce information ex ante about possible investments, promote the efficient allocation of capital, and mobilize and pool savings. Empirical studies also find that financial development is associated with reductions in the growth of the Gini and poverty (Beck, Demirgüç-Kunt, and Levine 2007; Honohan 2004).

- Unemployment, captured by the unemployment rate, is expected to be positively associated with income inequality because unemployed, inactive, and unskilled workers are more typically found among the bottom 20 percent of the income distribution (Martinez, Ayala, and Ruiz-Huerta 2001).

- Good governance, measured by the six worldwide governance indicators (WGI). The existing literature shows that good governance has a positive impact on pro-poor growth (Dollar and Kraay 2002; Kaufmann and Aart 2002; Kraay 2004) and is therefore expected to have the same impact on inclusive growth. 


\section{Pro-poor and inclusive growth: empirical evidence}

\section{Has growth been pro-poor and inclusive?}

Before analysing regressions, a simple plotting illustrates the tight link between poverty reduction and per capita income growth. In both transformed between- and within-variables, income growth is associated with higher income among the poor (figure 1).

As a starting point, the paper examines the impact of economic growth on the income of the poorest 20 percent and the poverty headcount at $\$ 2$ a day to examine the extent to which growth is pro-poor. The coefficient of interest is $\beta$, which gives the impact of economic growth on poverty reduction (the equation is in logarithm terms); $\gamma$ measures the effect of a change in the Gini index on poverty reduction.

Because the paper defines growth as pro-poor if it reduces poverty (Ravallion and Chen 1997), the results suggest that growth is generally pro-poor using the two indicators. A 1 percent increase in real GDP per capita leads to about a 1.4 percent increase in the income of the poor (table 1, column 5). A similar 1.0 percent increase in real GDP per capita leads to a decrease of about 2.3 percent in the poverty headcount (table 2, column 3 ). The results also show that inequality increases poverty.

Figure 1. Growth and the income of the poor

a. Between transformed variables

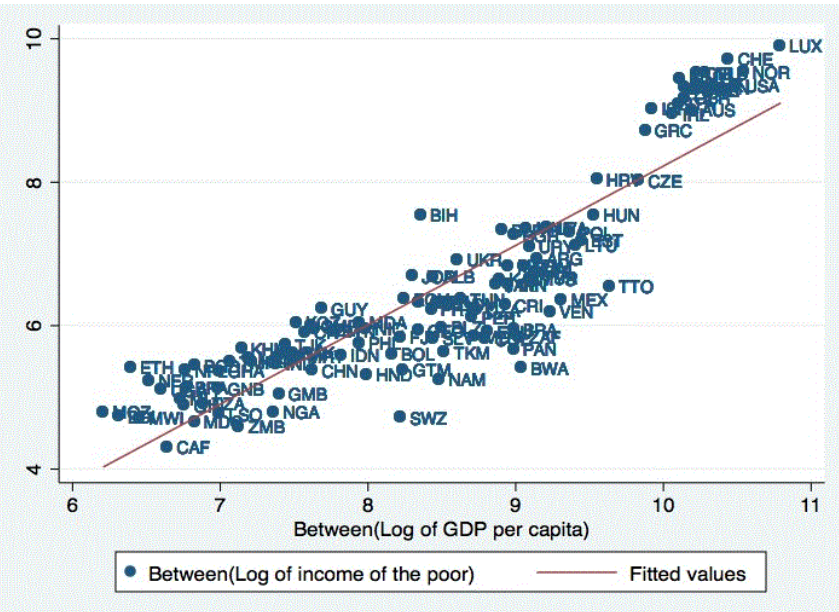

b. Within transformed variables

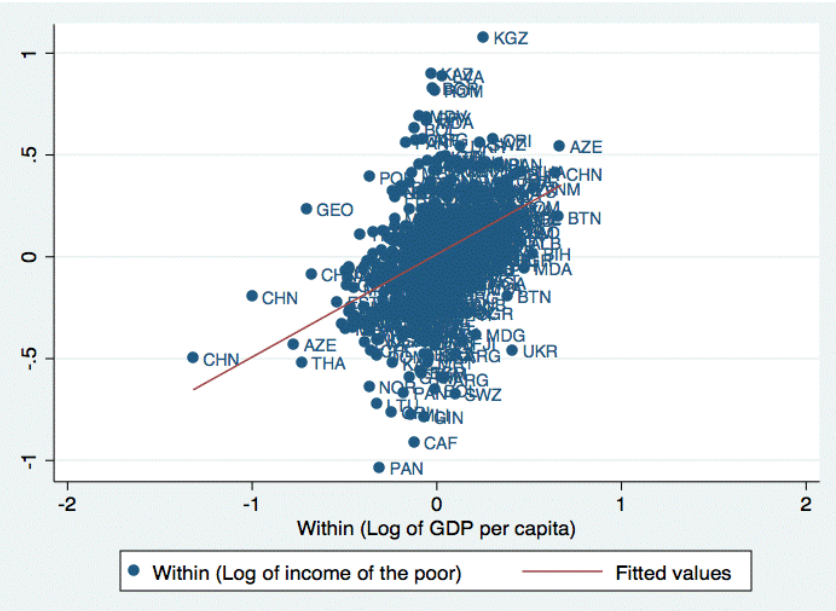


Table 1. Pro-poor growth regressions- income of the poorest 20 percent.

\begin{tabular}{|c|c|c|c|c|c|c|}
\hline & (1) & (2) & (3) & (4) & (5) & (6) \\
\hline Variables & $\ln y p$ & lnyp & lnyp & lnyp & lnyp & lnyp \\
\hline \multirow[t]{2}{*}{ Log of GDP per capita } & $0.60^{* * *}$ & $0.66^{* * *}$ & $1.11^{* * *}$ & $0.98 * * *$ & $1.42^{* * *}$ & $1.02^{* * *}$ \\
\hline & $(0.05)$ & $(0.05)$ & $(0.05)$ & $(0.03)$ & $(0.14)$ & $(0.08)$ \\
\hline \multirow[t]{2}{*}{ Log of Gini Index } & & $-1.37^{* * *}$ & & $-2.01 * * *$ & & $-1.64 * * *$ \\
\hline & & $(0.13)$ & & $(0.2)$ & & $(0.26)$ \\
\hline \multirow[t]{2}{*}{ Constant } & $1.47^{* * *}$ & $5.79 * * *$ & $-2.87^{* * *}$ & $5.6 * * *$ & $-5.53^{* * *}$ & $3.82 * *$ \\
\hline & $(0.49)$ & $(0.67)$ & $(0.44)$ & $(0.89)$ & $(1.27)$ & $(1.29)$ \\
\hline Observations & 517 & 426 & 517 & 426 & 517 & 426 \\
\hline R-squared & 0.21 & 0.4 & 0.8 & 0.9 & & \\
\hline $\mathrm{AR}(1)$ test & & & & & 0.66 & 0.51 \\
\hline $\mathrm{AR}(2)$ test & & & & & 0.3 & 0.23 \\
\hline P-Value Hansen test & & & & & 0.11 & 0.2 \\
\hline Number of countries & 112 & 109 & 112 & 109 & 112 & 109 \\
\hline Model & FE & FE & $\mathrm{BE}$ & $\mathrm{BE}$ & SYS-GMM & SYS-GMM \\
\hline
\end{tabular}

Table 2. Pro-poor growth regressions- poverty headcount ratio at $\$ 2$.

\begin{tabular}{lllll}
\hline & $(1)$ & $(2)$ & $(3)$ & $(4)$ \\
Variables & $\ln P$ & $\ln P$ & $\ln P$ & $\ln P$ \\
\hline Log of GDP per capita & $-1.024^{* * *}$ & $1.15^{* * *}$ & $-2.25^{* * *}$ & $-1.66^{* * *}$ \\
& $(0.13)$ & $(0.12)$ & $(0.44)$ & $(0.21)$ \\
Log of Gini Index & & $2.53^{* * *}$ & & $3.93^{* * *}$ \\
& & $(0.33)$ & & $(0.66)$ \\
Constant & $11.17^{* * *}$ & $2.84^{*}$ & $21.29^{* * *}$ & 1.88 \\
& $(1.13)$ & $(1.52)$ & $(3.64)$ & $(3.01)$ \\
\hline Observations & 424 & 421 & 424 & 421 \\
R-squared & 0.14 & 0.27 & & \\
AR(1) test & & & 0.9 & 0.81 \\
AR(2) test & & & 0.57 & 0.1 \\
P-Value Hansen test & & & 0.13 & 0.2 \\
Number of countries & 92 & 92 & 92 & 92 \\
Model & FE & FE & SYS-GMM & SYS-GMM \\
\hline
\end{tabular}

Note: Robust standard errors in parentheses: ${ }^{* * *} \mathrm{p}<0.01,{ }^{* *} \mathrm{p}<0.05,{ }^{*} \mathrm{p}<0.1$. Diagnostic tests (Hansen and first and second-order autocorrelations) reveal no evidence against the validity of the instruments used by the SYS-GMM estimator.

On the other hand, following Dollar and Kraay (2002), this section first examines the relationship between per capita income and a broad definition of inclusiveness, that is, the bottom quintile share of the income distribution (figure 2). Debates on inclusiveness usually focus on the incidence of poverty and the income distribution among individuals and households in society. Thus, income shares are conventional metrics for gauging the distributive impact of policies. 
As in the section on pro-poor growth, a two-step approach is followed by, first, assessing the impact of income growth on the bottom quintile income share and, second, by analysing the impact of governance. Because the paper considers growth as inclusive if income growth is associated with an increase in the bottom quintile share of the income distribution, growth is inclusive if $\beta$ is greater than zero. The results reported in table 3 show no evidence of inclusive growth (column 2, baseline model): the coefficient is positive, but not significant. ${ }^{8}$

Figure 2. Inclusive growth

a. Between transformed variables

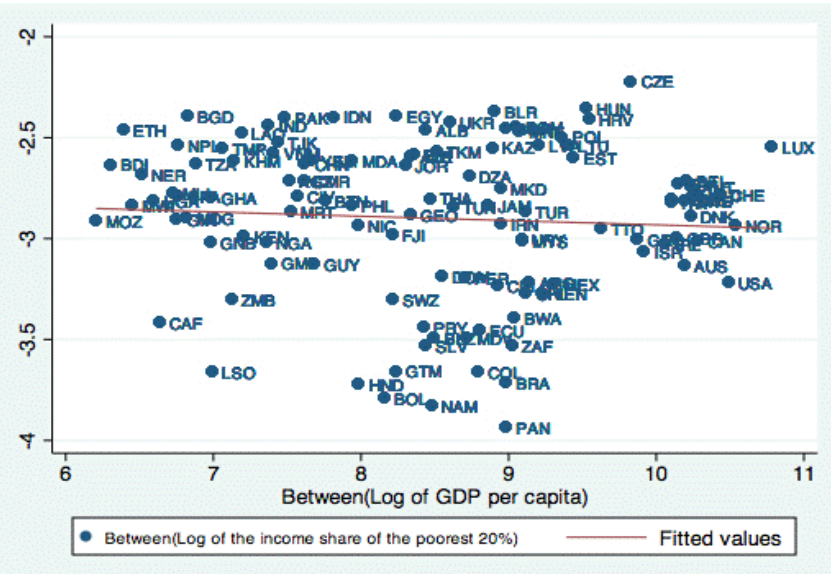

b. Within transformed variables

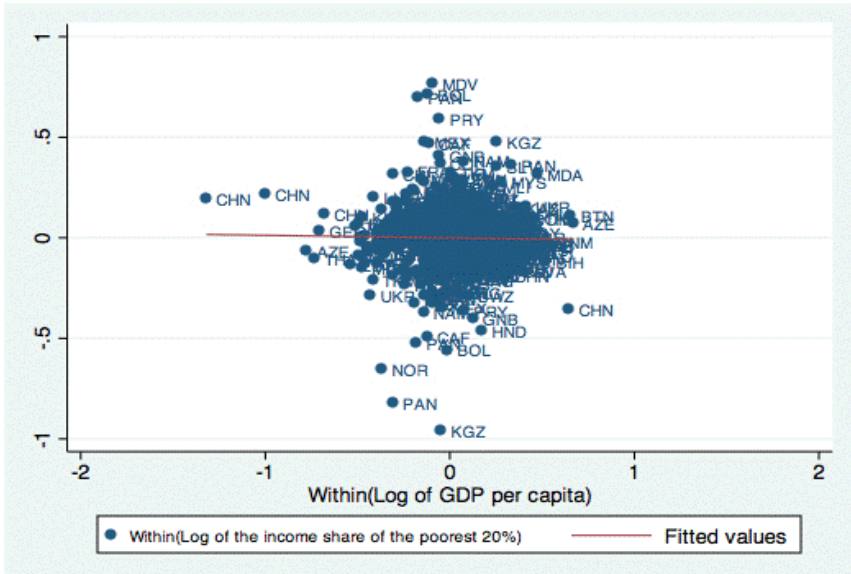

Table 3. Governance and inclusive growth regressions.

\begin{tabular}{|c|c|c|c|c|c|c|c|c|}
\hline Variables & $\begin{array}{l}(1) \\
\ln \mathrm{O}\end{array}$ & $\begin{array}{l}(2) \\
\ln \mathrm{O}\end{array}$ & $\begin{array}{l}\text { (3) } \\
\ln \mathrm{O}\end{array}$ & $\begin{array}{l}\text { (4) } \\
\operatorname{lnO}\end{array}$ & $\begin{array}{l}(5) \\
\operatorname{lnO}\end{array}$ & $\begin{array}{l}(6) \\
\ln \mathrm{O}\end{array}$ & (7) & $\begin{array}{l}(8) \\
\ln \mathrm{O}\end{array}$ \\
\hline Log of GDP per capita & 1.0 .1 & 0.11 & 0.08 & -0.77 & -0.03 & 0.37 & -0.25 & -0.15 \\
\hline & $(0.67)$ & $(0.08)$ & $(0.25)$ & $(0.67)$ & $(0.08)$ & $(0.51)$ & $(0.43)$ & $(0.26)$ \\
\hline Log of GDP per capita, squared & $\begin{array}{l}-0.06 \\
(0.03)\end{array}$ & & & & & & & \\
\hline Control of Corrup & & & $\begin{array}{l}0.04 \\
(0.24)\end{array}$ & & & & & \\
\hline Gov. Effectiveness & & & & $\begin{array}{l}0.84 * \\
(0.46)\end{array}$ & & & & \\
\hline Political Stability & & & & & $\begin{array}{l}-0.006 \\
(0.10)\end{array}$ & & & \\
\hline Regulatory quality & & & & & & $\begin{array}{l}0.35 \\
(0.44)\end{array}$ & & \\
\hline Rule of law & & & & & & & $\begin{array}{l}0.58 * \\
(0.33)\end{array}$ & \\
\hline Voice and Account & & & & & & & & $\begin{array}{l}-0.01 \\
(0.13)\end{array}$ \\
\hline Constant & $\begin{array}{l}-7.08^{* * * *} \\
(2.80) \\
\end{array}$ & $\begin{array}{l}-3.85^{* * *} \\
(0.74)\end{array}$ & $\begin{array}{l}-3.63 \\
(2.24) \\
\end{array}$ & $\begin{array}{l}3.76 \\
(5.80) \\
\end{array}$ & $\begin{array}{l}-2.62 * * * \\
(0.75) \\
\end{array}$ & $\begin{array}{l}-6.16 \\
(4.38) \\
\end{array}$ & $\begin{array}{l}-0.65 \\
(3.78) \\
\end{array}$ & $\begin{array}{l}-1.58 \\
(2.31) \\
\end{array}$ \\
\hline Observations & 522 & 522 & 330 & 330 & 330 & 330 & 330 & 330 \\
\hline AR(1) test & 0.31 & 0.32 & 0.48 & 0.15 & 0.44 & 0.09 & 0.45 & 0.57 \\
\hline $\mathrm{AR}(2)$ test & 0.13 & 0.17 & 0.59 & 0.87 & 0.32 & 0.71 & 0.66 & 0.26 \\
\hline P-Value Hansen test & 0.02 & 0.002 & 0.69 & 0.37 & 0.77 & 0.86 & 0.41 & 0.77 \\
\hline Number of countries & 112 & 112 & 110 & 110 & 110 & 110 & 110 & 110 \\
\hline Model & SYS-GMM & SYS-GMM & SYS-GMM & SYS-GMM & SYS-GMM & SYS-GMM & SYS-GMM & SYS-GMM \\
\hline
\end{tabular}

\footnotetext{
${ }^{8}$ In column (1), the log of GDP per capita and the square of GDP per capita are used as explanatory variables to consider the Kuznets relationship (Barro 2008; Woo et al. 2017). In the literature, the existing evidence of the Kuznets curve is mixed. Our data do not support evidence of the Kuznets inverted U-shaped link between GDP per capita and inequality (measured by the income shared of the poorest 20 percent).
} 


\section{Pro-poor and inclusive growth: the role of governance}

\section{Governance and pro-poor growth}

As a second step. the paper adds indicators of governance in the estimating equation to capture the impact of good governance on poverty reduction. All indicators of governance, except political stability and absence of violence, seem to have an impact on poverty (table 4). A one percent increase of the aggregated governance index, which combines political, economic and institutional features of good governance, increases the income of the poor by 14 percent. ${ }^{9}$ Because corrupt governments can distort decision making in favour of projects that profit the few rather than the many, reforms for good governance positively impact poverty reduction by providing better opportunities to the poor. This is most likely to happen through better rule of law (including property rights), which improve economic prospects and better ensure access to pro-poor public goods such health and education. Indeed, zooming on institutional governance, which is represented by rule of law, control of corruption and accountability, the results suggest that a better rule of law and control of corruption significantly increases the income of the poor. A government accountable to its people is also more prone to implement pro-poor policies than otherwise. This paper (table 4, columns 3 and 5) shows that regulatory quality and control of corruption have larger impacts on the income of the poor as compared to other governance indicators. An improvement in government effectiveness or regulatory quality positively impacts the income of the poor. A one point increase in government effectiveness and regulatory quality improves the income of the poor by respectively 35 and 42 percent. A one-point increase in the control of corruption leads to an increase of about 39 percent in the income of the poor.

In general, corruption impacts negatively economic growth by impeding some drivers of potential growth such as public and private investment, human capital accumulation, macroeconomic and financial stability, and total factor productivity (IMF 2016). Yet, corruption tends to have greater impacts for the poor. For instance, in a corrupt system, the provision of social services is inefficient in the way that the use of government-funded programs (for example health and education programs) tends to benefit to wealthier people in the society. As shown in Gupta, Davoodi, and Tiongson (2002), the misappropriation of funds from poverty reduction programs by well-connected individuals, reduces the impact of social programs on income distribution and poverty. Regulatory quality is also an important factor of poverty reduction. It matters to ensure that the regulation promotes the creation of an enabling environment that contributes to economic growth and the wellbeing of people in the society. Results found in this paper are consistent with previous empirical findings and robust when poverty headcount ratio is used as an alternative poverty indicator (appendix, table A5).

In this line, Acemoğlu and Robinson (2012, 3), in Why Nations Fail, argue that less

\footnotetext{
${ }^{9}$ The index is constructed through principal component analysis.
} 
developed countries such as Egypt are poor because "it [Egypt] has been ruled by a narrow elite that have organized society for their own benefit at the expense of the vast mass of people. Political power has been narrowly concentrated and has been used to create great wealth for those who possess it."

They defend that developed countries such as the United Kingdom and the United States grew successful because they created inclusive institutional and political arrangements that benefit society as a whole.

Table 4. Governance and pro-poor growth regressions.

\begin{tabular}{|c|c|c|c|c|c|c|c|}
\hline & (1) & (2) & (3) & (4) & (5) & (6) & (7) \\
\hline Variables & $\operatorname{lnyp}$ & $\operatorname{lnyp}$ & lnyp & $\operatorname{lnyp}$ & $\operatorname{lnyp}$ & $\operatorname{lnyp}$ & $\operatorname{lnyp}$ \\
\hline \multirow[t]{2}{*}{ Log of GDP per capita } & $0.94 * * *$ & $0.75^{* * *}$ & $0.87^{* * *}$ & $0.9^{* * *}$ & $0.85^{* * *}$ & $0.88^{* * *}$ & $0.83^{* * *}$ \\
\hline & $(0.15)$ & $(0.14)$ & $(0.13)$ & $(0.08)$ & $(0.12)$ & $(0.1)$ & $(0.7)$ \\
\hline \multirow[t]{2}{*}{ Log of Gini Index } & $-1.21 * * *$ & $-1.65 * * *$ & $-1.4 * * *$ & $-1.41 * * *$ & $-1.33 * * *$ & $-1.38 * * *$ & $-1.67 * * *$ \\
\hline & $(0.42)$ & $(0.33)$ & $(0.37)$ & $(0.31)$ & $(0.38)$ & $(0.3)$ & $(0.29)$ \\
\hline \multirow[t]{2}{*}{ Governance } & $0.14 * *$ & & & & & & \\
\hline & $(0.07)$ & & & & & & \\
\hline \multirow[t]{2}{*}{ Control of corrup } & & $0.39^{* * *}$ & & & & & \\
\hline & & $(0.13)$ & & & & & \\
\hline \multirow[t]{2}{*}{ Gov. Effectiveness } & & & $0.35^{* *}$ & & & & \\
\hline & & & $(0.15)$ & & & & \\
\hline \multirow[t]{2}{*}{ Political Stability } & & & & 0.08 & & & \\
\hline & & & & $(0.08)$ & & & \\
\hline \multirow[t]{2}{*}{ Regulatory quality } & & & & & $0.42 * * *$ & & \\
\hline & & & & & $(0.12)$ & & \\
\hline \multirow[t]{2}{*}{ Rule of law } & & & & & & $0.24 *$ & \\
\hline & & & & & & $(0.13)$ & \\
\hline \multirow[t]{2}{*}{ Voice and Account. } & & & & & & & $0.25 * * *$ \\
\hline & & & & & & & $(0.08)$ \\
\hline \multirow[t]{2}{*}{ Constant } & 2.94 & $6.22 * * *$ & $4.26^{* *}$ & $3.46^{* *}$ & $4.06^{* *}$ & $4.08^{* *}$ & $5.52 * * *$ \\
\hline & $(2.45)$ & $(2.14)$ & $(2.2)$ & $(1.51)$ & (1.96) & $(1.53)$ & $(1.43)$ \\
\hline Observations & 286 & 286 & 286 & 286 & 286 & 286 & 286 \\
\hline $\mathrm{AR}(1)$ test & 0.43 & 0.45 & 0.49 & 0.24 & 0.41 & 0.41 & 0.21 \\
\hline $\mathrm{AR}(2)$ test & 0.49 & 0.07 & 0.33 & 0.18 & 0.89 & 0.33 & 0.05 \\
\hline P-Value Hansen test & 0.05 & 0.01 & 0.14 & 0.05 & 0.04 & 0.15 & 0.07 \\
\hline Number of countries & 107 & 107 & 107 & 107 & 90 & 107 & 107 \\
\hline Model & SYS-GMM & SYS-GMM & SYS-GMM & SYS-GMM & SYS-GMM & SYS-GMM & SYS-GMM \\
\hline
\end{tabular}

Note: Robust standard errors in parentheses: ${ }^{* * *} \mathrm{p}<0.01,{ }^{* *} \mathrm{p}<0.05,{ }^{*} \mathrm{p}<0.1$. Diagnostic tests (Hansen and first and second-order autocorrelations) reveal no evidence against the validity of the instruments used by the SYS-GMM estimator.

\section{Governance and inclusive growth}

Inclusiveness involves dimensions other than poverty and income distribution, such as governance, which in itself impact income distribution. Building effective institutions could therefore be important to make growth inclusive. This raises the question about which key governance factors and mechanisms could facilitate growth and promote inclusiveness. 
To this end, the baseline model is estimated using the income share of the poor as dependent variable and governance indicators as explanatory variables. Results are shown in the six last columns of table 3. The inclusiveness coefficient is not significant for any of the specifications, thereby illustrating that growth has not been inclusive.

While other indicators of good governance are not significantly associated with the income share of the poorest 20 percent, results show that government effectiveness (economic governance) and rule of law (institutional governance) are key in increasing the income share of the poorest 20 percent. Government effectiveness has greater impact than rule of law: a one-point increase in the government effectiveness index increases the income share of the poorest 20 percent by 84 percent while a similar one-point increase in the rule of law index leads to an increase of 58 percent in the income share of the poorest 20 percent.

The results illustrate that economic growth should be complemented with liable and transparent public administration, effective government policies, and confidence in the rules of society, which could lead to a non-discriminatory redistribution of the gains of growth. The practice of inclusive growth requires effective implementation of policies and institutions allowing the share of benefits from economic growth. These policies could also support a fair income distribution and better social inclusion through better education systems, social insurance and labour markets. Indeed, as shown in Gupta et al. (2015), fiscal policy is an important tool for income distribution. For a country to attain inclusive growth besides government effectiveness, strong rule of law is needed. This institutional feature of good governance allows better property rights and business regulations, and effective enforcement by the legal system.

\section{Other determinants of pro-poor and inclusive growth}

In this subsection, the paper determines what other factors determine pro-poor and inclusive growth. It also assesses the robustness of results found in the previous sections after controlling for other determinants of poverty and inequality as identified in the empirical literature.

The results presented in table 5 confirm the main results: growth has been pro-poor as per capita income growth has positively and significantly impacted the income of the poor; and the control of corruption is positively associated with increases in the income of the poor. Controlling for other potential determinants of poverty also shows that better health services (captured by health care expenditure, lower infant mortality or lower prevalence of HIV), better access to education (captured by spending in education or secondary school enrolment) are individually associated with higher income of the poor. In addition, improvement in sanitation infrastructure and financial openness increase the income of the poor. ${ }^{10}$ Combining

\footnotetext{
${ }^{10}$ This paper does not find a significant effect of trade openness on the income of the poor. Results in the empirical literature are mixed on this. For instance, Lopez (2004) suggested that the impact of trade openness on the poor might vary according to the sectors in which the poor are concentrated. Measuring trade openness as
} 
these different factors into a single estimation could raise the issue of multicollinearity. Selectively introducing few variables together confirms the role of education, financial development, and financial openness in increasing the income of the poor.

Turning to inclusive growth regressions, table 6 shows important results. Findings confirm that growth has not been inclusive as growth in per capita income leads to a decrease in the income share of the poor. Inflation has a slightly positive effect on the income share of the bottom quintile. Trade openness and sanitation improvement have positive impacts: a 1.0 percent increase in trade openness increases the income share of the poor by 0.3 percent, while a similar increase in sanitation improvement increases the income share of the bottom quintile by 1 percent (Column 3). Unemployment and financial openness negatively impact the bottom quintile income share even though the coefficient is not significant. Besides, secondary school enrolment benefits the poor (Column 4). Estimates from the fifth specification show that financial development (M2) increases the income share of the poorest 20 percent by 0.1 percent. In a nutshell, government effectiveness, infrastructure improvement, trade openness, human capital and financial development are pro-inclusive policies.

Regressions of shared prosperity i.e. considering the share of the bottom 40 percent of the income distribution broadly confirm these results (table A6 in Appendix).

the volume of trade adjusted by a country's size and population, he found that while trade openness appears to increase poverty in the short run, it is negatively correlated with poverty in the long run. 
Table 5. Structural determinants of pro-poor growth.

\begin{tabular}{|c|c|c|c|c|c|c|c|c|c|c|c|}
\hline & (1) & (2) & (3) & (4) & (5) & (6) & (7) & (8) & (9) & (10) & (11) \\
\hline Variables & lnyp & $\operatorname{lnyp}$ & lnyp & lnyp & lnyp & lnyp & lnyp & lnyp & lnyp & lnyp & $\operatorname{lnyp}$ \\
\hline \multirow[t]{2}{*}{ Log of GDP per capita } & $0.65^{* * *}$ & $0.40^{* *}$ & $0.55^{* * *}$ & $0.91 * * *$ & $0.59^{* * *}$ & $0.46^{* * *}$ & $0.73^{* * *}$ & $0.72 * * *$ & $0.88^{* * *}$ & $0.55^{* * *}$ & $0.45^{* * *}$ \\
\hline & $(0.1)$ & $(0.18)$ & $(0.07)$ & $(0.15)$ & $(0.16)$ & $(0.18)$ & $(0.1)$ & $(0.1)$ & $(0.09)$ & $(0.11)$ & $(0.14)$ \\
\hline \multirow[t]{2}{*}{ Log of Gini Index } & $-1.73 * * *$ & & $-1.61 * * *$ & & $-1.08 * * *$ & $-0.92 * *$ & $-1.43 * * *$ & $-1.54 * * *$ & $-1.89 * * *$ & $-1.87 * * *$ & $-1.7 * * *$ \\
\hline & $(0.25)$ & & $(0.09)$ & & $(0.34)$ & $(0.53)$ & $(0.3)$ & $(0.31)$ & $(0.37)$ & $(0.26)$ & $(0.4)$ \\
\hline \multirow[t]{2}{*}{ Control of Corrup } & $0.35^{* * *}$ & $0.62^{* * *}$ & 0.012 & $0.33 * *$ & $0.43^{* * *}$ & $0.5 * * *$ & $0.42^{* * *}$ & $0.39^{* * *}$ & $0.22 * *$ & $0.4 * * *$ & $0.26^{*}$ \\
\hline & $(0.12)$ & $(0.14)$ & $(0.13)$ & $(0.14)$ & $(0.13)$ & $(0.16)$ & $(0.11)$ & $(0.13)$ & $(0.11)$ & $(0.12)$ & $(0.1)$ \\
\hline \multirow[t]{2}{*}{ Hegdp } & $0.06^{*}$ & & & & & & & & & & 0.03 \\
\hline & $(0.03)$ & & & & & & & & & & $(0.04)$ \\
\hline Mortality5 & & $-0.006 * *$ & & & & & & & & & \\
\hline pVIH & & $(0.000)$ & $-0.02 *$ & & & & & & & & \\
\hline & & & $(0.01)$ & & & & & & & & \\
\hline SpendingEdu & & & & $0.17 * * *$ & & & & & & & $0.06^{*}$ \\
\hline & & & & $(0.06)$ & & & & & & & $(0.03)$ \\
\hline SchoolSec & & & & & $\begin{array}{l}0.007 * * \\
(0.004)\end{array}$ & & & & & & \\
\hline Sanitation & & & & & & $0.013^{* *}$ & & & & & 0.005 \\
\hline & & & & & & & $(0.0006)$ & & & & $(0.001)$ \\
\hline M2 & & & & & & & & 0.001 & & & $0.006^{* *}$ \\
\hline & & & & & & & & $(0.002)$ & & & $(0.002)$ \\
\hline Openness & & & & & & & & & -0.002 & & -0.002 \\
\hline & & & & & & & & & $(0.002)$ & & $(0.002)$ \\
\hline FinOpenness & & & & & & & & & & 0.09 & $0.09 *$ \\
\hline & & & & & & & & & & $(0.06)$ & $(0.05)$ \\
\hline Constant & $7.1^{* * *}$ & $3.53^{* *}$ & $7.56^{* * *}$ & $-1.94 * * *$ & $4.88^{* * *}$ & $5.02 * *$ & $5.57^{* * *}$ & $5.95^{* * *}$ & $6.14 * * *$ & $8.65^{* * *}$ & $7.92^{* * *}$ \\
\hline & $(1.29)$ & $(1.71)$ & $(1.11)$ & $(1.34)$ & $(1.78)$ & $(2.61)$ & $(1.75)$ & (1.97) & $(1.69)$ & $(1.54)$ & $(1.66)$ \\
\hline Observations & 286 & 328 & 202 & 287 & 251 & 284 & 276 & 284 & 286 & 283 & 236 \\
\hline $\mathrm{AR}(1)$ test & 0.3 & 0.9 & 0.23 & 0.42 & 0.85 & 0.47 & 0.4 & 0.43 & 0.33 & 0.53 & 0.13 \\
\hline $\mathrm{AR}(2)$ test & 0.17 & 0.6 & 0.04 & 0.9 & 0.13 & 0.15 & 0.12 & 0.11 & 0.08 & 0.04 & 0.56 \\
\hline P-value Hansen test & 0.09 & 0.102 & 0.51 & 0.2 & 0.104 & 0.096 & 0.109 & 0.09 & 0.13 & 0.108 & 0.27 \\
\hline Number of countries & 107 & 110 & 70 & 103 & 102 & 106 & 104 & 107 & 107 & 105 & 95 \\
\hline Model & SYS-GMM & SYS-GMM & SYS-GMM & SYS-GMM & SYS-GMM & SYS-GMM & SYS-GMM & SYS-GMM & SYS-GMM & SYS-GMM & SYS-GMM \\
\hline
\end{tabular}


Table 6. Structural determinants of inclusive growth

\begin{tabular}{|c|c|c|c|c|c|c|}
\hline & (1) & (2) & (3) & (4) & (5) & (6) \\
\hline Variables & $\ln Q$ & $\ln Q$ & $\ln Q$ & $\ln Q$ & $\ln Q$ & $\ln Q$ \\
\hline \multirow[t]{2}{*}{ Log of GDP per capita } & -0.12 & $-0.23^{* *}$ & $-0.34 * *$ & $-0.27 * * *$ & $-0.44^{* * *}$ & $-0.51^{* * *}$ \\
\hline & $(0.11)$ & $(0.11)$ & $(0.13)$ & $(0.10)$ & $(0.15)$ & $(0.14)$ \\
\hline \multirow[t]{2}{*}{ Gov. Effectiveness } & $0.23 * *$ & 0.15 & $0.28 * *$ & 0.03 & $0.21^{*}$ & $0.24 * *$ \\
\hline & $(0.12)$ & $(0.11)$ & $(0.11)$ & $(0.08)$ & $(0.10)$ & $(0.11)$ \\
\hline \multirow[t]{2}{*}{ SpendingEdu } & 0.02 & 0.01 & -0.01 & & & \\
\hline & $(0.05)$ & $(0.03)$ & $(0.04)$ & & & \\
\hline \multirow[t]{2}{*}{ SchoolSec } & & & & $0.01 * * *$ & 0.005 & 0.002 \\
\hline & & & & $(0.002)$ & $(0.004)$ & $(0.004)$ \\
\hline \multirow[t]{2}{*}{ FinOpenness } & -0.08 & -0.06 & -0.06 & -0.02 & -0.10 & -0.03 \\
\hline & $(0.06)$ & $(0.04)$ & $(0.04)$ & $(0.04)$ & $(0.08)$ & $(0.04)$ \\
\hline \multirow[t]{2}{*}{ Openness } & 0.003 & 0.001 & $0.003^{*}$ & 0.001 & 0.001 & 0.001 \\
\hline & $(0.002)$ & $(0.001)$ & $(0.002)$ & $(0.001)$ & $(0.001)$ & $(0.001)$ \\
\hline \multirow[t]{2}{*}{ Inflation } & $0.001^{* *}$ & 0.00 & 0.00 & 0.00 & 0.003 & 0.001 \\
\hline & $(0.00)$ & $(0.00)$ & $(0.00)$ & $(0.00)$ & $(0.002)$ & $(0.00)$ \\
\hline \multirow[t]{2}{*}{ M2 } & -0.00 & -0.00 & -0.00 & 0.00 & $0.001 *$ & 0.00 \\
\hline & $(0.00)$ & $(0.001)$ & $(0.001)$ & $(0.001)$ & $(0.001)$ & $(0.001)$ \\
\hline \multirow[t]{2}{*}{ Sanitation } & & $0.009 * * *$ & $0.01 * *$ & & $0.009^{* *}$ & $0.012 * *$ \\
\hline & & $(0.003)$ & $(0.00)$ & & $(0.004)$ & $(0.005)$ \\
\hline \multirow[t]{2}{*}{ Unemployment } & & & -0.01 & & & -0.006 \\
\hline & & & $(0.01)$ & & & $(0.01)$ \\
\hline \multirow[t]{2}{*}{ Hegdp } & & & -0.001 & & & 0.02 \\
\hline & & & $(0.03)$ & & & $(0.03)$ \\
\hline \multirow[t]{2}{*}{ Constant } & $-2.17 * *$ & $-1.7^{* *}$ & -0.67 & $-1.44 *$ & -0.47 & 0.24 \\
\hline & $(0.92)$ & $(0.83)$ & $(0.98)$ & $(0.75)$ & (1.14) & $(1.05)$ \\
\hline Observations & 231 & 269 & 226 & 277 & 272 & 231 \\
\hline $\mathrm{AR}(1)$ test & 0.16 & 0.95 & 0.68 & 0.42 & 0.4 & 0.84 \\
\hline $\mathrm{AR}(2)$ test & 0.61 & 0.16 & 0.12 & 0.28 & 0.73 & 0.14 \\
\hline P-Value Hansen test & 0.55 & 0.43 & 0.81 & 0.45 & 0.08 & 0.91 \\
\hline Number of countries & 89 & 98 & 88 & 100 & 99 & 88 \\
\hline Model & SYS-GMM & SYS-GMM & SYS-GMM & SYS-GMM & SYS-GMM & SYS-GMM \\
\hline
\end{tabular}

Note: Robust standard errors in parentheses: ${ }^{* * *} \mathrm{p}<0.01,{ }^{* *} \mathrm{p}<0.05,{ }^{*} \mathrm{p}<0.1$. Diagnostic tests (Hansen and first and second-order autocorrelations) reveal no evidence against the validity of the instruments used by the SYS-GMM estimator. 


\section{Nonlinear and threshold estimations}

\section{Exogenous nonlinear estimation}

This section discusses a possible evidence of linearity or nonlinearity from two perspectives: (a) a differentiation by the quality of governance and $(b)$ a differentiation by the level of development. A simple test consists of exogenously splitting the sample according to the median level of the variables of interest (level of development or governance) as a threshold point.

Regarding the pro-poor regressions, the first step (a) consists in investigating the effect of growth and governance on the income of the poor as a function of the quality of governance. ${ }^{11}$ As in the previous section, the sample is split in two groups of countries according to the median level of governance indicators. Countries that are below the median are those that have lower governance quality while those above the median have greater governance quality. The results presented in the second and third columns of table 7 do not provide any evidence of a differentiated impact of growth on the income of the poor depending on the quality of governance. For instance, considering the indicator of control of corruption, the effect of a 1 percent increase in income per capita on the income of the poor goes from 0.82 to 0.81 . However, the quality of governance seems to matter for the income of the poor only in countries with relatively adequate level of governance. These findings are also robust to the introduction of additional control variables as in the previous section.

In the second step $(b)$, the paper also examines the impact of good governance on the income of the poor as a function of the level of development. ${ }^{12}$ Results reported in the first column of table 7 illustrate interesting heterogeneity. Higher growth has a larger impact on the income of the poor in more developed countries; growth increases income per capita more than proportionally in these countries. While better control of corruption increases the income of the poor in countries with per income above the median level $(\$ 5,227$ PPP constant 2005 international U.S. dollars), its impact is not significantly in less developed countries (countries with per capita income below the median level) ${ }^{13}$. This differentiation is robust to the introduction of additional control variables (education, health, trade openness, financial development, etc.) discussed in the previous section. The finding suggests that, in opposite to higher income countries, less developed countries may not be successful in controlling corruption in such a way that it could influence the income of the less fortunate.

\footnotetext{
${ }^{11}$ The quality of governance is captured by two indicators: the aggregated governance indicator and control of corruption.

12 The paper retains control of corruption as a proxy for good governance in pro-poor growth regressions.

13 This paper relies on an approach that consists in splitting the sample below and above the median of variables of interest in order to capture the potential nonlinear relationship (see Giuliano and Ruiz-Arranz, 2009). Unlike regressions with interaction terms, this approach relies on a threshold point, which is the median level of variables of interest (log of GDP per capita and control of corruption).
} 
Table 7. Pro-poor growth and governance: non-linearity.

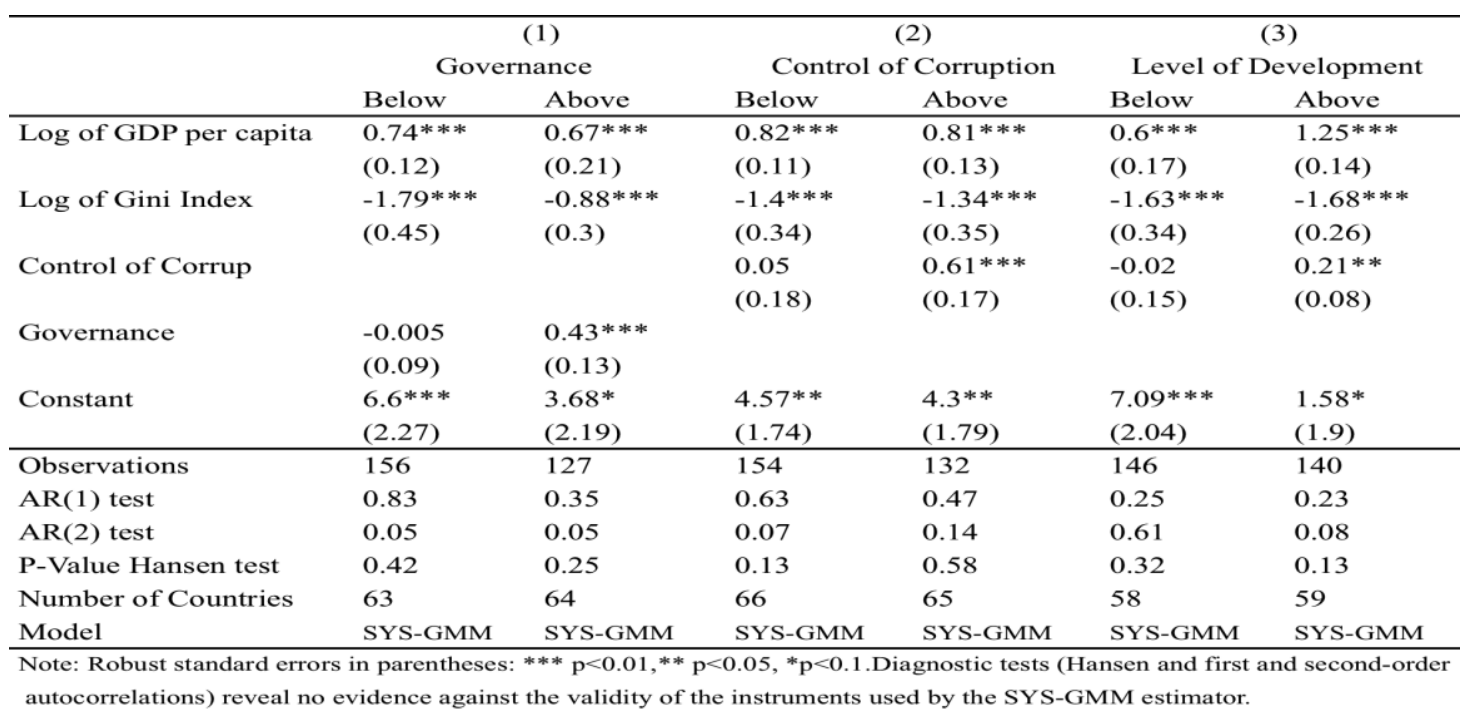

Turning to inclusive growth regressions, results (step $(a)$ ) show that growth has not been inclusive neither in countries below the median level of governance and government effectiveness nor above these thresholds (table 8, columns 1 and 2). The coefficient associated to inclusive growth is negative and significant for countries with lower governance level while this coefficient is negative but not significant for countries with higher level of governance.

The second step $(b)$ as in the pro-poor growth regressions consists in examining the impact of good governance on the income share of the poor as a function of the level of development. Findings suggest that growth has not been inclusive in less developed countries while the coefficient associated with inclusive growth is positive but not significant for more developed countries (table 8, column 3). In addition, coefficients associated with the two governance indicators (government effectiveness and governance) are not significant.

Table 8. Inclusive growth and governance: non-linearity.

\begin{tabular}{|c|c|c|c|c|c|c|}
\hline & \multirow{2}{*}{\multicolumn{2}{|c|}{$\begin{array}{c}(1) \\
\text { Governance }\end{array}$}} & \multirow{2}{*}{\multicolumn{2}{|c|}{$\begin{array}{c}(2) \\
\text { Government Effectiveness }\end{array}$}} & \multirow{2}{*}{\multicolumn{2}{|c|}{$\begin{array}{c}\text { (3) } \\
\text { Level of Development }\end{array}$}} \\
\hline & & & & & & \\
\hline & Below & Above & Below & Above & Below & Above \\
\hline \multirow[t]{2}{*}{ Log of GDP per capita } & $-0.14 * *$ & -0.034 & $-0.11^{*}$ & -0.08 & $-0.20 *$ & 0.17 \\
\hline & $(0.06)$ & $(0.06)$ & $(0.059)$ & $(0.079)$ & $(0.08)$ & $(0.11)$ \\
\hline \multirow[t]{2}{*}{ Governance } & -0.045 & 0.06 & & & & \\
\hline & $(0.058)$ & $(0.05)$ & & & & \\
\hline \multirow[t]{2}{*}{ Gov. Effectiveness } & & & 0.03 & 0.15 & 0.08 & -0.07 \\
\hline & & & $(0.18)$ & $(0.105)$ & $(0.11)$ & $(0.08)$ \\
\hline \multirow[t]{2}{*}{ Constant } & $-1.79 * * *$ & $-2.71 * * *$ & $-1.96 * * *$ & -2.30 & $-1.25^{*}$ & $-4.55 * * *$ \\
\hline & $(0.46)$ & $(0.53)$ & $(0.47)$ & $(0.65)$ & $(0.64)$ & $(1.08)$ \\
\hline Observations & 161 & 169 & 160 & 170 & 148 & 182 \\
\hline P-Value Hansen test & 1.00 & 1.00 & 1.00 & 1.00 & 1.00 & 1.00 \\
\hline Number of Countries & 64 & 66 & 60 & 63 & 59 & 61 \\
\hline Model & SYS-GMM & SYS-GMM & SYS-GMM & SYS-GMM & SYS-GMM & SYS-GMM \\
\hline
\end{tabular}




\section{Endogenous nonlinear estimation: Panel Smooth Transition Regression}

In this section, the paper further analyses the nonlinear relationship between pro-poor, inclusive growth and governance. The paper introduces and estimate the Panel Smooth Transition Regression (PSTR) model, developed by Gonzalez, Tersvirta and Dijk (2005), to accommodate other issues that have arisen in the literature on the relationship between poverty reduction, economic growth and good governance, and to test the robustness of our results.

The section first $(i)$ investigates the impact of growth on the income of the poor as a function of the level of governance quality and (ii) examines the impact of good governance on the income of the poor as a function of development level. Second, it (iii) assesses the impact of growth on the income share of the bottom quintile as a function of the level of governance quality and (iv) examines the nonlinear relationship between governance and the income share of the bottom quintile as a function of the level of development. An alternative procedure to test these nonlinear relationships would have been the introduction of interaction terms, for instance between governance indicators and the level of development, in the regressions. While this approach allows accounting for nonlinearity, it does not permit to explicitly model the dynamics exerted by such nonlinearity.

Compared with the introduction of interaction terms and the median value as an exogenous threshold, the PSTR has first the advantage to allow the governance-growth nexus to vary over time according to the level of development. Second, it allows the relationship between growth and income of the poor to vary over time according to the level of governance quality. The PSTR specification considers the speed of transition from one regime to the other with the passage from one regime to another being gradual. Additionally, it provides the threshold values of (i) the level of governance quality and (ii) the level of development at which the dynamics of the relationships change.

The PSTR methodology compared to SYS-GMM has the advantage to account for sufficient heterogeneity given the disparity in the sample of study. It allows the coefficients of equations (3), (6), (8) and (9) to vary across countries and over time, depending on the level of the threshold variable. As the PSTR model is a regime-switching model, the change in the coefficients is gradual and smooth.

The general PSTR model that allows for $(r+1)$ different regimes is as follows:

$y_{i t}=u_{i}+\lambda_{t}+\beta_{0} X_{i t}+\sum_{j=1}^{r} \beta_{j}^{\prime} X_{i t} g_{j}\left(q_{i t}^{(j)}, \gamma_{j}, \delta_{j}\right)+\varepsilon_{i t}$

Where the transition functions $g_{j}\left(q_{i t}^{(j)}, \gamma_{j}, \delta_{j}\right), j=1, \ldots, r$, are given by:

$$
g\left(q_{i t}, \gamma, \delta\right)=\left[1+\exp \left[-\gamma \prod_{j=1}^{m}\left(q_{i t}-\delta_{j}\right)\right]\right]^{-1}, \gamma>0 \text { and } \delta_{1}<\delta_{2} \ldots<\delta_{m}
$$


with polynomial degrees $m_{j} . \delta=\left(\delta_{1}, \ldots, \delta_{m}\right)^{\prime}$ is a vector of location parameters and $\gamma$ represents the smooth parameter.

While SYS-GMM directly deals with potential endogeneity issues, PSTR does not. Therefore, to handle potential endogeneity issues by reducing the risk of reverse causality, the PSTR models in this paper use one-period lagged values of all explanatory variables that could be potentially endogenous. This approach follows the recent empirical literature (see Allegret et al., 2014).

\section{Estimation of Models (i) and (ii)}

For the first model $(i)$, the PSTR model with $r=1$ is defined as follows:

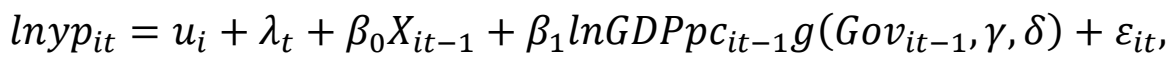

where $\ln y p_{i t}$ denotes the logarithm of income of the 20 percent poorest; $X_{i t-1}$ represents a vector of control variables: log of GDP per capita, public spending on education as a percentage of GDP, inflation, money and quasi-money (M2/GDP), inflation, improvement in sanitation, trade openness as a percentage of GDP and financial openness at period $t-1$ for country $i$ (linear part of the model); $\operatorname{lnGDPp} c_{i t-1}$ is the logarithm of the GDP per capita (nonlinear part); Gov $v_{i t-1}$ represents the governance indicator, control of corruption; $u_{i}$ is an individual fixed effect; $\lambda_{t}$ represents time effects; and $\varepsilon_{i t}$ stands for the idiosyncratic error. Moreover, the transition function is given by a logistic function:

$g\left(G o v_{i t-1}, \gamma, \delta\right)=\left[1+\exp \left[-\gamma\left(G o v_{i t-1}-\delta\right)\right]\right]^{-1}, \gamma>0$

Where $g\left(\operatorname{Gov}_{i t-1}, \gamma, \delta\right)$ is a continuous function and it is bounded between [0,1]. It depends on the transition function i.e. control of corruption $\left(G_{o v} v_{i t-1}\right)$, a smooth parameter $\gamma$, and a threshold parameter $\delta$.

Accordingly, the marginal effect of income growth depending on governance quality and is given by:

$e_{i t}=\frac{\partial \operatorname{lnyp} p_{i t}}{\partial \ln G D P p c_{i t-1}}=\beta_{0}+\beta_{1} g\left(G_{o v} v_{i t-1}, \gamma, \delta\right)$

The properties of the transition function involve:

$$
{ }_{0} e_{i t}{ }_{0}+{ }_{1} \text { if }{ }_{1}>0 \text { or }{ }_{0}+{ }_{1} e_{i t}{ }_{0} \text { if }{ }_{1}<0
$$

When estimating the parameters of the PSTR model, the individual effects $u_{i}$ are removed by eliminating individual-specific means and thus it is a transformed model by nonlinear least squares that one estimates (González et al., 2005). The testing procedure of González et al. 
(2005) consists of: first testing the linearity against the PSTR model, and second determining the number $r$ of transition function. Considering equation (3), the linearity check consists in testing: $H_{0}: \gamma=0$ or $H_{0}: \beta_{1}=0$. Then three standard tests can be applied using these statistics: Lagrange Multiplier of Fisher $\left(L M_{F}\right)$, Wald test $(L M)$, and Pseudo Likelihood-ratio $(L R T)$.

Tests of linearity also show evidence of nonlinearity (table 9). Table 10 reports the estimates of the PSTR model. It shows that all the control variables have the expected signs, except public spending on education. Results also show that depending on the transition function ${ }^{14}$, the effects of income growth on the income of the poor are positive and significant (table 10). The effect of growth on the income of the poorest 20 percent increases with the control of corruption. Figure 3 illustrates these findings.

Control of corruption is good for pro-poor growth, especially after reaching a threshold (index greater than -0.8). For countries where the control of corruption is stronger, it leads to much larger impacts of per capita income growth on the income of the poor than in countries where corruption is more prevalent (lower levels of control of corruption).

The second PSTR model (ii) with $r=1$ is written as follows:

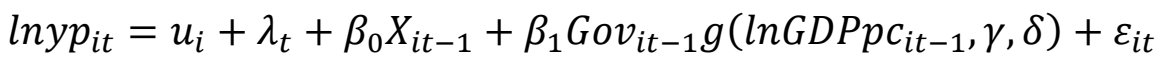

where the logistic transition function is:

$g\left(\ln G D P p c_{i t-1}, \gamma, \delta\right)=\left[1+\exp \left[-\gamma\left(\ln G D P p c_{i t-1}-\delta\right)\right]\right]^{-1}, \gamma>0$

$X_{i t-1}$ is a vector of control variables as in model $(i)$.

Additionally, equation (5) allows the marginal effect of governance on the income of the poor to depend on the level of development and is given by:

$e_{i t}=\frac{\partial \operatorname{lnyp}_{i t}}{\partial G o v_{i t-1}}=\beta_{0}+\beta_{1} g\left(\ln G D P p c_{i t-1}, \gamma, \delta\right)$

The properties of equation (8) remain the same as in the first step.

The results presented in table 9 suggest no evidence of nonlinearity regarding the effects of governance on the income of the poor as a function of the level of development. These findings contrast with previous results, which show that the impact of good governance on the income of the poor is greater in countries with high development levels.

\footnotetext{
${ }^{14}$ The transition function depends upon the governance indicator: control of corruption.
} 
Table 9. Results of linearity for the PSTR models (i) and (ii).

\begin{tabular}{lcc}
\hline \multicolumn{1}{c}{ Threshold variables } & $\begin{array}{c}\text { Control of } \\
\text { corruption }\end{array}$ & $\begin{array}{c}\text { Level of } \\
\text { Development }\end{array}$ \\
\hline $\mathrm{N}^{\circ}$ of transition function $\left(r^{*}\right)$ & 1 & 1 \\
$\left(\mathrm{H}_{0}: r=0 v s \mathrm{H}_{1}: r=1\right)$ & & \\
LRT Test of linearity & $26.357(0.000)$ & $0.000(0.993)$ \\
Wald Test & $23.387(0.001)$ & $0.000(0.993)$ \\
Fisher Test & $2.567(0.021)$ & $0.000(0.994)$ \\
& & \\
$\left(\mathrm{H}_{0}: r=1\right.$ v $\left.\mathrm{H}_{1}: r=2\right)$ & $3.614(0.823)$ & $0.276(0.599)$ \\
LRT Test of no remaining nonlinearity & $3.554(0.829)$ & $0.276(0.559)$ \\
Wald Test & $0.248(0.971)$ & $0.179(0.673)$ \\
Fisher Test & 360 & 360 \\
Number of observations & 36 & 36 \\
Number of countries & & \\
\hline Num
\end{tabular}

Note: The test of linearity has an asymptotic F(1,TN-N-1) distribution under the null hypothesis and $\mathrm{F}(1, \mathrm{TN}-\mathrm{N}-2)$ for the no remaining nonlinearity test with $\mathrm{N}$ the number of individuals and $\mathrm{T}$ the number of periods. For statistics of periods. For statistics, the p-values are in parentheses. As the PSTR is also a fixed effect model, the PSTR package requires at least two lines with no missing values for all the dependent, explanatory and threshold variables. These models keep only countries for which there are at least three lines with no missing values for the variables used. 36 countries meet these criteria.

Table 10. Parameter estimates for the PSTR model $(i)$.

\begin{tabular}{|c|c|c|}
\hline $\begin{array}{l}\text { Dependent variable: Log of income of the } \\
\text { poorest } 20 \text { percent }\end{array}$ & Coefficient & t-statistic \\
\hline Log of GDP per capita $t-1$ & 0.4848 & 2.55426765 \\
\hline Log of GDP per capita $t-1{ }^{*} g$ & 0.3793 & 2.0164806 \\
\hline SpendingEdu $\mathrm{t}-1$ & -0.05418 & -1.2082962 \\
\hline $\mathrm{M} 2_{\mathrm{t}-1}$ & 0.0006608 & 0.2543495 \\
\hline Inflation $_{\mathrm{t}-1}$ & -0.001737 & -3.5814433 \\
\hline Sanitation $\mathrm{t}-1$ & 0.01925 & 1.55618432 \\
\hline Openness $\mathrm{t}-1$ & 0.002967 & 1.22908036 \\
\hline FinOpenness $t-1$ & 0.01546 & 0.56177326 \\
\hline Location parameter & -0.811 & \\
\hline Smooth parameter & 4.224 & \\
\hline Number of observations & 360 & \\
\hline Number of countries & 36 & \\
\hline
\end{tabular}

Note: $g$ is the transition function and depends on the threshold variable: control of corruption, the location and smooth parameters. 
Figure 3. Marginal impact of income growth on the income of the poor

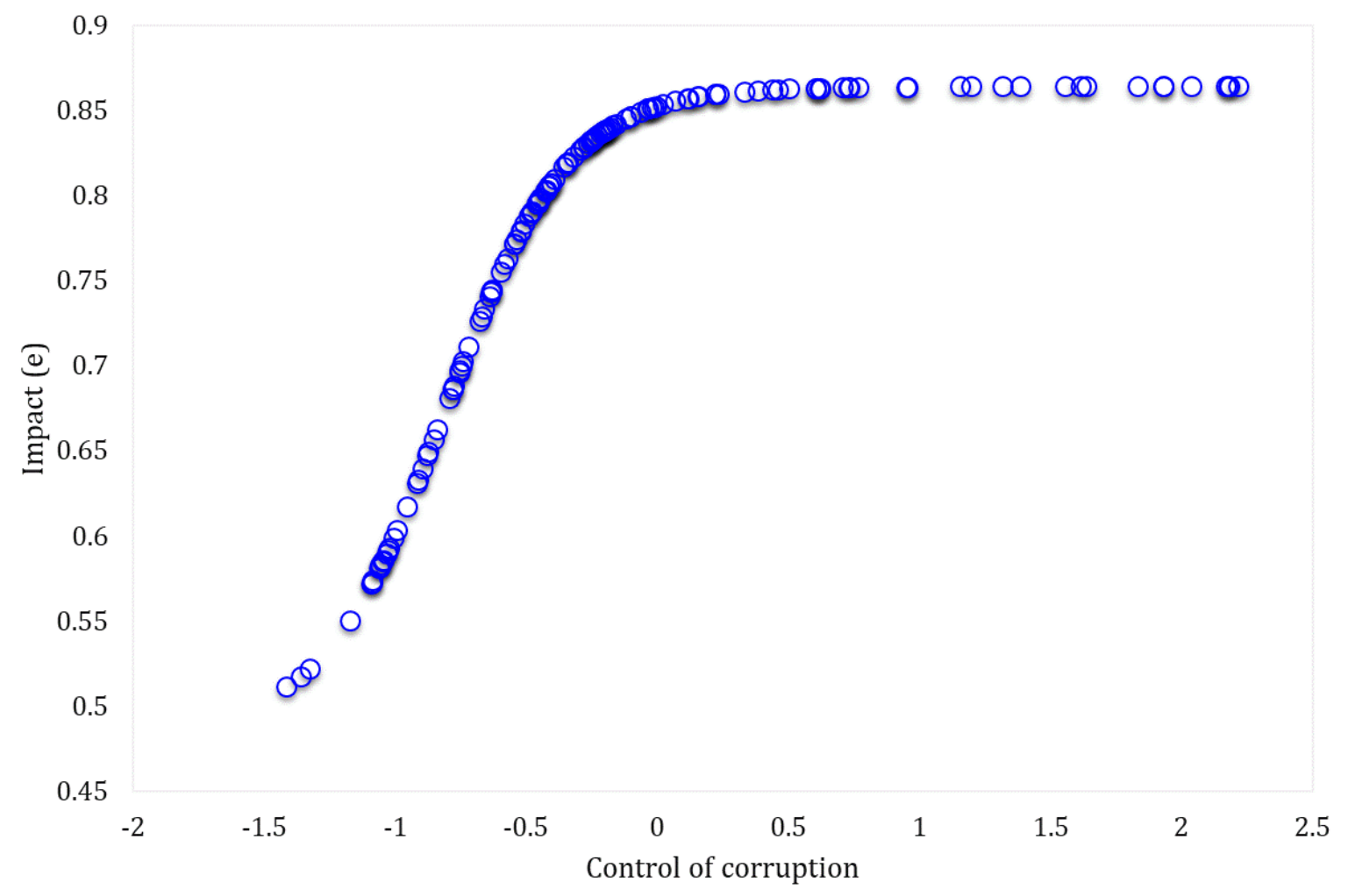

Estimation of Models (iii) and (iv)

This section tests the nonlinear relationship between: (iii) government effectiveness and the income share of the poorest 20 percent as a function of the level of development (equation 8) and (iv) growth and the income share of the poorest 20 percent as a function of the level of government effectiveness (equation 9).

$\ln Q_{i t}=u_{i}+\lambda_{t}+\beta_{0} X_{i t-1}+\beta_{1} \operatorname{lnGDPp} c_{i t-1} g\left(\operatorname{Gov}_{i t-1}, \gamma, \delta\right)+\varepsilon_{i t}$

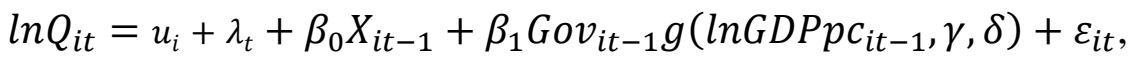

where $\ln Q_{i t}$ denotes the logarithm of income share of the 20 percent poorest; $X_{i t-1}$ represents a vector of control variables including secondary school enrolment, inflation, improvement in sanitation, trade openness, financial openness and unemployment rate at time $t-1$; oov $_{i t-1}$ represents the governance indicator, government effectiveness at time $t-1$; $\operatorname{lnGDPp} c_{i t-1}$ is the logarithm of the GDP per capita; $u_{i}$ is an individual fixed effect; and $\varepsilon_{i t}$ stands for the idiosyncratic error. ${ }^{15}$

\footnotetext{
${ }^{15}$ The paper retains government effectiveness because this is the main significant variable in the inclusive growth regressions.
} 
The results in table 11 show no evidence of nonlinearity considering either the impact of growth on the income share of the poorest 20 percent as a function of government effectiveness or the effect of government effectiveness on the income share of the poorest 20 percent depending on the level of development.

Table 11. Results of linearity for the PSTR models (iii) and (iv).

\begin{tabular}{lcc}
\hline \multicolumn{1}{c}{ Threshold variables } & $\begin{array}{c}\text { Government } \\
\text { Effectiveness }\end{array}$ & $\begin{array}{c}\text { Level of } \\
\text { Development }\end{array}$ \\
\hline $\mathrm{N}^{\circ}$ of transition function $\left(r^{*}\right)$ & 1 & 1 \\
$\left(\mathrm{H}_{0}: r=0 v s \mathrm{H}_{1}: r=1\right)$ & $2.195(0.143)$ & $2.750(0.102)$ \\
LRT Test of linearity & $2.170(0.141)$ & $2.711(0.100)$ \\
Wald Test & $1.457(0.232)$ & $1.831(0.181)$ \\
Fisher Test & & \\
& $0.061(0.804)$ & $0.152(0.696)$ \\
$\left(\mathrm{H}_{0}: r=1 v s \mathrm{H}_{1}: r=2\right)$ & $0.061(0.804)$ & $0.152(0.696)$ \\
LRT Test of no remaining nonlinearity & $0.039(0.844)$ & $0.097(0.757)$ \\
Wald Test & 320 & 320 \\
Fisher Test & 32 & 32 \\
\hline Number of observations & & \\
Number of countries & & \\
Note: The test of linearity has an asymptotic F(1,TN-N-1) distribution under the null hypothesis and F(1,TN-N-2) \\
for the no remaining nonlinearity test with $\mathrm{N}$ the number of individuals and $\mathrm{T}$ the number of periods. For \\
statistics of periods. For statistics, the p-values are in parentheses. As the PSTR is also a fixed effect model, the \\
PSTR package requires at least two lines with no missing values for all the dependent, explanatory and threshold \\
variables. These models keep only countries for which there are at least three lines with no missing values for the \\
variables used. 32 countries meet these criteria.
\end{tabular}

\section{Conclusion and discussion}

This paper examines, first, the extent to which growth has been pro-poor and inclusive by assessing, respectively, the impacts of income growth on poverty reduction and on the bottom share of the income distribution. Second, it investigates the effects of good governance in reducing poverty and attaining inclusive growth and assesses the factors that have been driving these outcomes. Third, the paper tests the nonlinear impacts of growth on poverty and inclusion.

Using a sample of 112 countries over 1975-2012, the paper finds that growth is generally pro-poor. Incomes of the poorest 20 percent rise, while the poverty headcount ratio at $\$ 2$-aday decreases with mean per capita incomes as economic growth proceeds. But inequality reduces this effect. The paper also finds that, globally, growth has not been inclusive. A striking finding is that the combination of political, economic, and institutional features of good governance improves the income of the poor and decreases poverty. The control of corruption and regulatory quality have the most positive impact on the incomes of the poor. However, only two features of governance (government effectiveness and the rule of law) 
have positive and significant effects on inclusive growth because they increase the income share of the poorest 20 percent.

The results suggest that enhancing human capital through health care and education spending, infrastructure improvement, and financial development are the main factors positively influencing poverty reduction and inclusive growth. The results also suggest that programs such as fighting infant mortality and HIV/AIDS are pro-poor. Finally, using the PSTR approach, the study finds evidence of a nonlinear relationship on the impact of growth on poverty. The impact of growth on the incomes of the poor is an increasing function of the control of corruption. However, the impact of growth on inclusiveness is linear.

This paper highlights that important elements in pro-poor and inclusive strategies include continued efforts to strengthen governance, control corruption, advance government effectiveness, and promote economic and social fairness. In addition, policies to attain propoor and inclusive growth need to be more broad-based by focusing on social development, including education, health care, infrastructure and financial development. 


\section{Appendix}

Table A1. Country list.

Albania, Algeria, Argentina, Armenia, Australia, Azerbaijan, Bangladesh, Belarus, Belgium, Belize, Bhutan, Bolivia, Bosnia and Herzegovina, Botswana, Brazil, Bulgaria, Burkina Faso, Burundi, Cambodia, Cameroon, Canada, Central African Republic, Chile, China, Columbia, Costa Rica, Cote d'Ivoire, Croatia, Czech Republic, Denmark, Dominican Republic, Ecuador, Arab Republic of Egypt, El Salvador, Estonia, Ethiopia, Fiji, Finland, France, The Republic of Gambia, Georgia, Germany, Ghana, Greece, Guatemala, Guinea, Guinea-Bissau, Guyana, Honduras, Hungary, India, Indonesia, Islamic Republic of Iran, Ireland, Israel, Italy, Jamaica, Jordan, Kazakhstan, Kenya, Kyrgyz Republic, Lao PDR, Latvia, Lesotho, Lithuania, Luxembourg, Macedonia FYR, Madagascar, Malawi, Malaysia, Maldives, Mali, Mauritania, Mexico, Moldova, Montenegro, Mozambique, Namibia, Nepal, Netherlands, Nicaragua, Niger, Nigeria, Norway, Pakistan, Panama, Paraguay, Peru, Philippines, Poland, Romania, South Africa, Swaziland, Sweden, Switzerland, Tajikistan, Tanzania, Thailand, Timor-Leste, Trinidad and Tobago, Tunisia, Turkey, Turkmenistan, Uganda, Ukraine, United Kingdom, United States, Uruguay, Venezuela, Vietnam, Republic of Yemen, Zambia. 
Table A2. Description of variables.

\begin{tabular}{lll}
\hline Variable & Source & Description/Definition \\
\hline Survey means & POVCALNET, LIS & $\begin{array}{l}\text { POVCALNET measures welfare by income or consumption as determined in the surveys. Regarding LIS, } \\
\text { DKK calculate survey means of disposable income directly from the micro survey data on household level. }\end{array}$ \\
$\operatorname{lnyp}$ & POVCALNET, LIS & Logarithm of Income of the poorest 20 percent of the income distribution \\
$\ln Q$ & POVCALNET, LIS & Logarithm of the share of the Income of the 20 percent of the income distribution \\
$\operatorname{lnBot.40}$ & POVCALNET, LIS & Logarithm of the share of the Income of the 40 percent of the income distribution \\
$\ln P$ & WDI, World Bank & Logarithm of Poverty headcount ratio at \$2 a day (PPP) in percentage of population \\
$\ln Y$ & WDI, World Bank & Logarithm of GDP per capita based on purchasing power parity (PPP constant 2005 international dollar) \\
& Logarithm of GINI index. Gini index measures the extent to which the distribution of income or \\
$\log$ of gini index & Consumption expenditure among individuals or households within an economy deviates from a perfectly \\
& equal distribution
\end{tabular}

Governance variables

Voice and accountability

WGI, World Bank

It reflects perceptions of the extent to which a country's citizens are able to participate in selecting their

Control of corruption

WGI, World Bank

government, as well as freedom of association and mediat
approximately from -2.5 to 2.5 (strong performance)

Government Effectiveness

WGI, World Bank

by elites and private interests

Regulatory quality

WGI, World Bank

It describes perceptions of the quality of public and civil services, the quality of policy design and implementation, and the reliability of the government's duty to such policies

Regulatory quatity
Rule of law

WGI, World Bank

It defines perceptions of the capability of the government to formulate and realize sound policies and regulations

Political Stability and absence of violence

WGI, World Bank

It reflects insights of the extent to which agents have confidence in and accept the rules of society (property rights, the police, the courts, the quality of contract implementation) It defines perceptions of the likelihood that the government will be destabilized or defeated by unconstitutional or violent processes, including terrorism and politically-motivated violence

Structural factors

Hegdp

WDI, World Bank

Public health expenditure (\% GDP). It consists of recurrent and capital spending from government (central

Mortality5

WDI, World Bank

and local) budgets, external borrowings and grants (including donations from international agencies and nongovernmental organizations), and social (or compulsory) health insurance funds

$\mathrm{pVIH}$

WDI, World Bank

Under-five mortality rate per 1,000 live births is the probability per 1,000 that a newborn baby will die

before reaching age five, if subject to current age-specific mortality rates

SpendingEdu

Prevalence of HIV refers to the percentage of people ages 15-49 who are infected with HIV

Public expenditure on education as \% of GDP is the total public expenditure on education expressed as a

WDI, World Bank percentage of the Gross Domestic Product (GDP) in a given year. Public expenditure on education includes government spending on educational institutions (both public and private), education administration, and transfers/subsidies for private entities (students/households and other private entities)

Gross enrolment ratio (GER). Secondary. All programs. Total is the total enrolment in secondary education,

SchoolSec

WDI, World Bank

regardless of age, expressed as a percentage of the population of official secondary education age. GER can exceed $100 \%$ due to the inclusion of over-aged and under-aged students because of early or late school entrance and grade repetition

Sanitation

WDI, World Bank

Improved Sanitation ( $\%$ of population with access). Access to an improved sanitation structure refers to the percentage of the population using an improved sanitation structure

Inflation, consumer prices (annual \%) Inflation as measured by the consumer price index reflects the annual

Inflation

WDI, World Bank

percentage change in the cost to the average consumer of acquiring a basket of goods and services that may be fixed or changed at specified intervals, such as yearly

M2

WDI, World Bank

Money and quasi-money (M2) as \% of GDP

Openness

WDI, World Bank

Trade openness is the sum of exports and imports of goods and services measured as a share of GDP

The Chinn-Ito index (KAOPEN) is an index measuring a country's degree of capital account openness. The

FinOpenness

WDI, World Bank

index is based on the binary dummy variables that codify the tabulation of restrictions on cross-border

financial transactions reported in the IMF's Annual Report on Exchange Arrangements and Exchange

Restriction. Source: http://web.pdx.edu/ ito/kaopen_Chinn-Ito_hi0523.pdf

Unemployment

WDI, World Bank

Unemployment, total ( $\%$ of total labor force) is the share of the labor 
Table A3. Descriptive statistics of main variables.

\begin{tabular}{|c|c|c|c|c|c|c|c|c|c|}
\hline \multirow[t]{2}{*}{ Variables } & \multirow[t]{2}{*}{ Mean } & \multicolumn{2}{|c|}{ Standard Deviation } & \multicolumn{2}{|c|}{ Max } & \multicolumn{2}{|c|}{ Min } & \multirow{2}{*}{$\begin{array}{l}\text { Number of } \\
\text { Observations }\end{array}$} & \multirow{2}{*}{$\begin{array}{l}\text { Number of } \\
\text { Countries }\end{array}$} \\
\hline & & Between & Within & Between & Within & Between & Within & & \\
\hline $\begin{array}{l}\text { Log of income of the } \\
\text { poorest } 20 \text { percent } \\
\text { Log of poverty }\end{array}$ & 6.71 & 1.46 & 0.27 & 9.89 & 7.79 & 4.3 & 5.67 & 531 & 112 \\
\hline Headcount ratio & 2.75 & 1.73 & 0.63 & 4.55 & 5.39 & -2.78 & -1.49 & 434 & 92 \\
\hline Log of GDP per capita & 8.47 & 1.17 & 0.25 & 10.79 & 9.79 & 6.21 & 7.15 & 944 & 112 \\
\hline Log of Gini index & 3.68 & 0.23 & 0.09 & 4.23 & 4.09 & 3.16 & 3.31 & 456 & 112 \\
\hline Control of corruption & -0.05 & 0.97 & 0.17 & 2.43 & 0.7 & -1.18 & -0.69 & 557 & 112 \\
\hline Government Effectiveness & 0.01 & 0.93 & 0.15 & 2.12 & 0.79 & -1.44 & -0.57 & 557 & 112 \\
\hline Political Statility & -0.16 & 0.84 & 0.27 & 1.48 & 1.07 & -1.94 & -1.39 & 557 & 112 \\
\hline Regulatory quality & 0.06 & 0.87 & 0.18 & 1.81 & 1.06 & -1.97 & -0.55 & 557 & 112 \\
\hline Rule of law & -0.1 & 0.94 & 0.15 & 1.93 & 0.54 & -1.47 & -0.83 & 557 & 112 \\
\hline Voice and Accountability & -0.01 & 0.89 & 0.17 & 1.6 & 0.49 & -1.9 & -1.09 & 557 & 112 \\
\hline
\end{tabular}

Table A4. Correlations between explanatory variables and lagged and differenced instruments used in the SYS-GMM estimation. ${ }^{16}$

\begin{tabular}{|c|c|c|c|c|c|c|}
\hline Variables & $\begin{array}{l}\text { Log of GDP } \\
\text { per capita }\end{array}$ & $\begin{array}{l}\text { Log of Gini } \\
\text { index }\end{array}$ & $\begin{array}{l}\text { Lag_1(Log of } \\
\text { GDP per capita) }\end{array}$ & $\begin{array}{l}\text { Lag_ I(Log of } \\
\text { Gini index) }\end{array}$ & $\begin{array}{l}\text { Diff (Log of } \\
\text { GDP per capita) }\end{array}$ & $\begin{array}{l}\text { Diff (Log of } \\
\text { Gini index) }\end{array}$ \\
\hline Log of GDP per capita & 1 & & & & & \\
\hline Log of Gini index & 0.06 & 1 & & & & \\
\hline Lag_I (Log of GDP per capita) & 0.98 & 0.07 & 1 & & & \\
\hline Lag__ (Log of Gini index) & 0.03 & 0.89 & 0.02 & 1 & & \\
\hline Diff (Log of GDP per capita) & 0.08 & -0.05 & -0.07 & 0.07 & 1 & \\
\hline Diff (Log of Gini index) & 0.03 & 0.03 & 0.08 & -0.41 & .0 .28 & 1 \\
\hline
\end{tabular}

Note: if correlations are small, instruments are weakly correlated with the offending explanatory variable, thas instruments are poor predictors of the of the endogenous predictor. In this case, lagged variables of log of GDP per capita and of log of Gini are good instruments, but variables in in difference are are a little weak because correlations are smaller than 0.1 .

${ }^{16}$ Table A4 presents correlations for table 1 (Benchmark results) in which the paper uses only lag 1 as instruments. 
Table A5. Governance indicators and pro-poor growth regressions.

\begin{tabular}{|c|c|c|c|c|c|c|c|}
\hline \multirow[b]{2}{*}{ Variables } & (1) & (2) & (3) & (4) & (5) & (6) & (7) \\
\hline & $\ln \mathrm{P}$ & $\ln \mathrm{P}$ & $\ln \mathrm{P}$ & $\ln \mathrm{P}$ & $\ln \mathrm{P}$ & $\ln \mathrm{P}$ & $\ln \mathrm{P}$ \\
\hline \multirow[t]{2}{*}{ Log of GDP per capita } & $-1.29 * * *$ & $-1.76^{* * *}$ & $-1.58 * * *$ & $-1.51 * * *$ & $-1.17 * * *$ & $-1.81 * * *$ & $-1.55 * * *$ \\
\hline & $(0.27)$ & $(0.29)$ & $(0.29)$ & $(0.18)$ & $(0.25)$ & $(0.27)$ & $(0.2)$ \\
\hline \multirow{2}{*}{ Log of Gini Index } & $2.99 * * *$ & $2.63 * * *$ & $3.06^{* * *}$ & $2.28 * *$ & $3.59 * * *$ & $2.66 * * *$ & $2.75^{* * *}$ \\
\hline & $(0.78)$ & $(0.71)$ & $(0.7)$ & $(0.7)$ & $(0.68)$ & $(0.64)$ & $(0.68)$ \\
\hline \multirow[t]{2}{*}{ Governance } & $-0.3^{*}$ & & & & & & \\
\hline & $(0.16)$ & & & & & & \\
\hline \multirow[t]{2}{*}{ Control of corrup } & & -0.1 & & & & & \\
\hline & & $(0.35)$ & & & & & \\
\hline \multirow[t]{2}{*}{ Gov. Effectiveness } & & & -0.007 & & & & \\
\hline & & & $(0.35)$ & & & & \\
\hline \multirow[t]{2}{*}{ Political Stability } & & & & $-0.31 * *$ & & & \\
\hline & & & & $(0.15)$ & & & \\
\hline \multirow[t]{2}{*}{ Regulatory quality } & & & & & $-0.44^{*}$ & & \\
\hline & & & & & $(0.25)$ & & \\
\hline \multirow[t]{2}{*}{ Rule of law } & & & & & & 0.14 & \\
\hline & & & & & & $(0.32)$ & \\
\hline \multirow[t]{2}{*}{ Voice and Account. } & & & & & & & $-0.4^{*}$ \\
\hline & & & & & & & $(0.23)$ \\
\hline \multirow[t]{2}{*}{ Constant } & 2.15 & $7.46^{*}$ & 4.45 & $6.60^{*}$ & -0.9 & $7.9 * *$ & $5.22 *$ \\
\hline & $(0.58)$ & $(3.84)$ & $(3.55)$ & $(3.17)$ & $(2.85)$ & $(3.17)$ & $(3.13)$ \\
\hline Observations & 284 & 284 & 284 & 284 & 284 & 284 & 284 \\
\hline $\mathrm{AR}(1)$ test & 0.1 & 0.24 & 0.23 & 0.2 & 0.22 & 0.3 & 0.12 \\
\hline $\mathrm{AR}(2)$ test & 0.03 & 0.01 & 0.01 & 0.04 & 0.06 & 0.02 & 0.01 \\
\hline P-Value Hansen test & 0.22 & 0.15 & 0.21 & 0.10 & 0.08 & 0.38 & 0.24 \\
\hline Number of countries & 90 & 90 & 90 & 90 & 90 & 90 & 90 \\
\hline Model & SYS-GMM & SYS-GMM & SYS-GMM & SYS-GMM & SYS-GMM & SYS-GMM & SYS-GMM \\
\hline
\end{tabular}

Note: Robust standard errors in parentheses: ${ }^{* * *} \mathrm{p}<0.01,{ }^{* *} \mathrm{p}<0.05,{ }^{*} \mathrm{p}<0.1$. Diagnostic tests (Hansen and first and second-order autocorrelations) reveal no evidence against the validity of the instruments used by the SYS-GMM estimator. 
Table A6. Shared prosperity and structural variables.

\begin{tabular}{|c|c|c|c|c|c|c|}
\hline & (1) & (2) & (3) & (4) & (5) & (6) \\
\hline Variables & $\operatorname{lnBot} .40$ & $\operatorname{lnBot} .40$ & $\operatorname{lnBot} .40$ & $\operatorname{lnBot} .40$ & $\operatorname{lnBot} .40$ & $\operatorname{lnBot} .40$ \\
\hline \multirow[t]{2}{*}{ Log of GDP per capita } & -0.01 & $-0.16^{* *}$ & $-0.24 * *$ & $-0.19 * * *$ & $-0.31 * * *$ & $-0.35 * * *$ \\
\hline & $(0.06)$ & $(0.07)$ & $(0.09)$ & $(0.07)$ & $(0.1)$ & $(0.1)$ \\
\hline \multirow[t]{2}{*}{ Gov. Effectiveness } & $0.14^{*}$ & $0.12 *$ & $0.19 * *$ & 0.02 & $0.16^{* *}$ & $0.15^{* *}$ \\
\hline & $(0.08)$ & $(0.07)$ & $(0.08)$ & $(0.06)$ & $(0.07)$ & $(0.07)$ \\
\hline \multirow[t]{2}{*}{ Spending in Education } & 0.02 & 0.00 & -0.00 & & & \\
\hline & $(0.03)$ & $(0.02)$ & $(0.02)$ & & & \\
\hline \multirow[t]{2}{*}{ SchoolSec } & & & & $0.007 * * *$ & $0.004^{* *}$ & 0.001 \\
\hline & & & & $(0.002)$ & $(0.003)$ & $(0.002)$ \\
\hline \multirow[t]{2}{*}{ FinOpenness } & -0.04 & -0.04 & -0.03 & -0.01 & -0.06 & -0.00 \\
\hline & $(0.03)$ & $(0.02)$ & $(0.03)$ & $(0.03)$ & $(0.05)$ & $(0.03)$ \\
\hline \multirow[t]{2}{*}{ Openness } & $0.003^{* *}$ & 0.00 & $0.002^{* *}$ & 0.001 & 0.001 & 0.001 \\
\hline & $(0.001)$ & $(0.001)$ & $(0.001)$ & $(0.001)$ & $(0.001)$ & $(0.001)$ \\
\hline \multirow[t]{2}{*}{ Inflation } & $0.00^{*}$ & 0.00 & -0.03 & 0.00 & 0.003 & 0.001 \\
\hline & $(0.00)$ & $(0.00)$ & $(0.00)$ & $(0.00)$ & $(0.002)$ & $(0.00)$ \\
\hline \multirow[t]{2}{*}{ M2 } & -0.00 & -0.00 & $-0.001 *$ & 0.00 & 0.00 & 0.00 \\
\hline & $(0.00)$ & $(0.001)$ & $(0.001)$ & $(0.00)$ & $(0.00)$ & $(0.001)$ \\
\hline \multirow[t]{2}{*}{ Sanitation } & & $0.006 * * *$ & $0.007 * *$ & & $0.006^{* *}$ & $0.008^{* *}$ \\
\hline & & $(0.002)$ & $(0.003)$ & & $(0.003)$ & $(0.003)$ \\
\hline \multirow[t]{2}{*}{ Unemployment } & & & -0.00 & & & -0.005 \\
\hline & & & $(0.00)$ & & & $(0.007)$ \\
\hline \multirow[t]{2}{*}{ Health/GDP } & & & 0.00 & & & 0.02 \\
\hline & & & $(0.02)$ & & & $(0.02)$ \\
\hline \multirow[t]{2}{*}{ Constant } & $-2.03 * * *$ & $-1.01^{*}$ & -0.33 & $-0.89^{*}$ & -0.15 & 0.26 \\
\hline & $(0.51)$ & $(0.58)$ & $(0.69)$ & $(0.53)$ & $(0.78)$ & $(0.74)$ \\
\hline Observations & 274 & 269 & 226 & 277 & 272 & 231 \\
\hline $\mathrm{AR}(1)$ test & 0.17 & 0.32 & 0.31 & 0.63 & 0.49 & 0.99 \\
\hline $\mathrm{AR}(2)$ test & 0.8 & 0.31 & 0.25 & 0.44 & 0.67 & 0.18 \\
\hline P-Value Hansen test & 0.55 & 0.72 & 0.86 & 0.22 & 0.03 & 0.94 \\
\hline Number of countries & 99 & 98 & 88 & 100 & 99 & 88 \\
\hline Model & SYS-GMM & SYS-GMM & SYS-GMM & SYS-GMM & SYS-GMM & SYS-GMM \\
\hline
\end{tabular}

Notes: The dependent variable is the share of the bottom 40 percent in the income distribution, in logarithm.

Robust standard errors in parentheses: ${ }^{* *} \mathrm{p}<0.01,{ }^{* *} \mathrm{p}<0.05,{ }^{*} \mathrm{p}<0.1$. Diagnostic tests (Hansen and first and second-order autocorrelations) reveal no evidence against the validity of the instruments used by the SYS-GMM estimator. 


\section{References}

Acemoğlu, D., and J. Robinson. 2012. Why Nations Fail: The origins of power, prosperity, and poverty. 1st ed. New York: Crown, 529.

Agénor, P. 1998. "Stabilization Policies, Poverty, and the Labor Market." mimeo, IMF and World Bank, Washington, DC.

Agénor, P. 2004. "Does globalization hurt the poor?." International Economics and Economic Policy 1 (1): 21-51.

Albanesi, S. 2007. "Inflation and inequality." Journal of Monetary Economics 54 (4): 10881114.

Alesina, A., and D. Rodrik. 1994. "Distributive Politics and Economic Growth." Quarterly Journal of Economics 109 (2): 465-490.

Allegret, J., C. Couharde, D. Coulibaly, and V. Mignon. 2014. "Current accounts and oil price fluctuations in oil-exporting countries: The role of financial development." Journal of International Money and Finance 47(C): 185-201.

Arrelano, M., and O. Bover. 1995. "Another look at the instrumental variable estimation of error-components models." Journal of Econometrics 68 (1): 29-51.

Balakrishman, R., C. Steinberg, and M. Syed. 2013. "The Elusive Quest for Inclusive Growth: Growth, Poverty, and Inequality in Asia” IMF Working Paper WP/13/152.

Barro, R. 2008. "Inequality and Growth Revisited," Asian Development Bank Working Paper Series on Regional Economic Integration, No. 11, January.

Barro, R., and X. Sala-i-Martin. 2004. Economic Growth. Cambridge Mass., MIT.

Beck, T., A. Demirgüç-Kunt, and R. Levine. (2007). "Finance, Inequality, and Poor.” Journal of Economic Growth 12 (1): 27-49.

Van der Berg, S. 2008. Poverty and Education. International Academy of Education (IAE) and the International Institute for Educational Planning (IIEP). France: UNESCO.

Berg, A., and J. Ostry. 2011. "Inequality and Unsustainable Growth: Two Sides of the Same Coin?.” IMF Staff Discussion Note 11/08. International Monetary Fund.

Gupta, S., M. Keen, B. Clements, and R. de Mooij (eds). 2015. Inequality and Fiscal Policy. Washington, DC: International Monetary Fund. 
Corak, M. 2013. "Income Inequality, Equality of Opportunity, and Intergenerational Mobility.” Journal of Economic Perspectives 27 (3): 79-102.

De Gregorio, J., and J. Lee. 2002. "Education and Income Inequality: New Evidence from Cross-country Data." Review of Income and Wealth 48 (3): 395-416.

Deininger, K., and L. Squire. 1998. "A New Data Set Measuring Income Inequality." The World Bank Economic Review 10 (3): 565-591.

Dollar, D. and A. Kraay. 2002. "Growth is Good for the Poor." Journal of Economic Growth 7 (3): 195-225.

Dollar, D., T. Kleineberg, and A. Kraay. 2016. "Growth Still Is Good for the Poor." European Economic Review 81 (C): 68-85.

Forbes, K. J. 2000. "A Reassessment of the Relationship Between Inequality and Growth." The American Economic Review 90 (4): 869-887.

Fischer, S., and F. Modigliani. 1978. "Towards an Understanding of the Real Effects and Costs of Inflation.” Weltwirfschaftltiche Archiv, Band 114: 810-833.

Giuliano, P., and M. Ruiz-Arranz. 2009. "Remittances, financial development, and growth." Journal of Development Economics 90 (1): 144-152.

Gonzalez, A., T. Tersvirta, and D. v. Dijk. 2005. "Panel smooth transition regression models." Working Paper Series in Economics and Finance No. 604. Stockholm School of Economics.

Goudie, A., and P. Ladd. 1999. "Economic growth, Poverty and Inequality." Journal of International Development 11 (2): 77-195.

Guillaumont-Jeanneney, S., and K. Kpodar. 2011. "Financial Development and Poverty Reduction: Can There Be a Benefit Without a Cost?.” Journal of Development Studies 47 (1): 143-163.

Gupta, S., H. Davoodi, and E. Tiongson. 2002. "Corruption and the Provision of Health Care and Education Services." in Governance, Corruption, and Economic Performance, edited by Abed G. T., and S. Gupta. Washington: International Monetary Fund.

Honohan, P. 2004. "Financial Development, Growth and Poverty: How Closer are the Links?.” World Bank Policy Research Working Paper 3203

International Monetary Fund. 2007. Globalization and Inequality. World Economic Outlook: $31-65$ 
International Monetary Fund. 2016. "Corruption: Costs and Mitigating Strategies." Fiscal Affairs and Legal Departments, Staff Discussion Notes SDN 16/05

Kanbur, R. 2000. "Income Distribution and Development" in Atkinson A. B., and F. Bourguignon (editors), Handbook of Income Distribution, 791-841.

Kaufmann, D., and A. Kraay. 2002. "Growth Without Governance.” World Bank Policy Research Working Paper No. 2928. World Bank Development Research Group.

Kaufmann D., A. Kraay, and P. Zodio-Lobaton. 1999. "Governance matters.” World Bank Policy Research Working Paper No. 2196.

Kaufmann, D., A. Kraay, and M. Mastruzzi. 2005. "Governance Matters IV: Governance Indicators for 1996-2004.” World Bank Policy Research Working Paper No. 3630.

King, R. G, and R. Levine. 1993. "Finance and Growth: Schumpeter Might Be Right." The Quarterly Journal of Economics 108 (3): 717-737.

Knight, J. B., and R. H. Sabot. 1983. "Educational Expansion and the Kuznets Effect." American Economic Review 73 (5): 1132-1136.

Kpodar, K., and R. Singh. 2011. "Does Financial Structure Matter for Poverty? Evidence from Developing Countries.” World Bank Policy Research Working Paper WPS5915.

Kraay, A. 2004. "When Is Growth Pro-Poor? Cross-Country Evidence." The World Bank Development Research Group (DECRG), IMF Working Paper No. 04/47.

Krugman, P. 2008. "Trade and Wages, Reconsidered." Brookings Papers on Economic Activity 39 (1): 103-137.

Kuznets, S. 1955. "Economic Growth And Income Inequality." American Economic Review 45 (1): 1-28.

Le Goff, M. and R. J. Singh. 2014. "Does trade reduce poverty? A view from Africa." Journal of African Trade 1(1): 5-14.

Levine, R. 2005. "Finance and Growth: Theory and Evidence." in Aghion, P. and S. Durlauf (editors), Handbook of Economic Growth, edition 1, volume 1, chapter 12, pages 865-934 Elsevier.

Levine, R., N. Loayza, and T. Beck. 2000. "Financial Intermediation and Growth: Causality and Causes.” Journal of Monetary Economics 46 (1): 31-77. 
Lopez, H. 2004. "Pro-growth, pro-poor: is there a tradeoff ?." World Bank, Policy Research Working Paper No. 3378.

Martinez, R., L. Ayala and J. Ruiz-Huerta. 2001. "The Impact of Unemployment on Inequality and Poverty in OECD Countries.” Economics of Transition 9 (2): 417-47.

Meschi, E., and M. Vivarelli. 2007. "Globalization and Income Inequality.” IZA Discussion Paper No.2958, July.

Powers. E. T. 1995. "Inflation, unemployment, and poverty revisited." Economic Review, Federal Reserve Bank of Cleveland Q (III): 2-13.

Rauniyar, G., and R. Kanbur. 2010. "Inclusive Development: a review and synthesis of Asian Development Bank literature.” Journal of the Asia Pacific Economy 15 (4): 455-469.

Ravallion, M. 2001. "Growth, Inequality and Poverty: Looking Beyond the Averages." World Bank Policy Research Working Paper No. 2558.

Ravallion, M., and S. Chen. 1997. "What Can New Survey Data Tell Us about Recent Changes in Distribution and Poverty?.” World Bank Economic Review 11 (2): 357-382.

Ravallion, M., and S. Chen. 2003. "Measuring Pro-Poor Growth." World Bank Policy Research Working Paper No. 2666.

Resnick, D., and B. Regina. 2006. "Does Good Governance Contribute to Pro-Poor Growth? A Review of the Evidence from Cross-country Studies." International Food Policy Research Institute, Washington, DC.

United Nations Development Programme, 1997. "Governance for sustainable human development." UNDP policy document, New York.

White, H., and E. Anderson. 2001. "Growth versus Distribution: Does the Pattern of Growth Matter?.” Development Policy Review 19 (3): 267-289.

Woo, J., E. Bova, T. Kinda, and Y. S. Zhang. 2017. "Distributional Consequences of Fiscal Adjustments: What Do the Data Say?.” IMF Economic Review 65 (2): 273-307.

World Bank. 1992. Governance and development. Washington, DC: The World Bank. http://documents.worldbank.org/curated/en/604951468739447676/Governance-anddevelopment 